\title{
Indonesia's Financial Markets and Monetary Policy Dynamics Amid the COVID-19 Pandemic
}

\author{
Eric Alexander Sugandi ${ }^{1}$ (D)
}

Accepted: 1 October 2021 / Published online: 19 October 2021

(c) The Author(s), under exclusive licence to Springer Japan KK, part of Springer Nature 2021

\begin{abstract}
We discuss the impacts of the COVID-19 pandemic on Indonesia's financial markets and monetary policy dynamics. We explore five types of financial markets in Indonesia: (1) the Rupiah (IDR) interbank money market; (2) the US Dollar (USD) interbank money market; (3) government conventional bond (SUN) markets; (4) the stock market; and (5) the USD/IDR spot market. We examine Bank Indonesia's (BI)'s three monetary policy instruments: (1) BI 7-day Reverse Repo Rate (the policy rate); (2) minimum reserve requirement ratios for banks (GWM); and (3) BI's monetary operations. We find that several policy instruments have significant impacts on specific financial markets before and during the pandemic, i.e., the policy rate on the IDR and USD interbank money market, the IDR GWM on the medium-term SUN market, and the foreign exchange (FX) GWM on the FX market. We also find that the COVID-19 pandemic strengthened the impacts of BI's policy instruments on particular financial markets during the pandemic than the pre-pandemic period. We suggest BI continues to maintain the stability of financial markets to support the government efforts to restore the economy from the fiscal side.
\end{abstract}

Keywords COVID-19 · Monetary policy $\cdot$ Indonesia's financial markets · Bank Indonesia

JEL Classification E58 - G10

\section{Introduction}

The Indonesian government announced the first positive COVID-19 case in Indonesia on 2 March 2020. Since then, the number of new cases reported has increased rapidly. On 31 March 2020, the Indonesian government declared a large-scale social

Eric Alexander Sugandi

esugandi@adbi.org; ericsugandi@gmail.com

1 Asian Development Bank Institute, Kasumigaseki Building 8th Floor, 3 Chome-2-5

Kasumigaseki, Chiyoda-ku, Tokyo 100-6008, Japan 
distancing (PSBB) policy to slow the spread of the disease. As Indonesia's economy was at a high risk of entering a recession, the government ended the PSBB and introduced the 'new normal' policy in early June 2020 to slowly resume economic activities. The government gradually opened nine economic sectors in July 2020, although the number of new COVID-19 cases continued to increase.

To mitigate the negative economic impacts of COVID-19, the government announced the first fiscal stimulus package in late February 2020 and the second fiscal stimulus package on 13 March 2020. The government issued Government Regulation in Lieu of Law (Perppu) No. 1/2020 on 31 March 2020 that granted the government, the central bank (Bank Indonesia), and other related agencies the capacity to implement discretionary economic policies. On the same occasion, the government announced the third fiscal stimulus package, which was much bigger than the previous ones. In July 2020, Perppu No. 1/2020 was replaced by the legally stronger Undang-Undang (Law) No. 2/2020. The government later increased the 2020 budget deficit target from $1.8 \%$ of nominal GDP to $6.3 \%$. The budget deficit increase will be mostly financed through the issuance of government debt securities (Surat Berharga Negara, SBN). The government launched the National Economic Recovery Program (PEN) in May 2020 containing specific programs to revive the economy.

Bank Indonesia (BI) runs expansionary monetary policies to stimulate the economy. From January 2020 to the end of September 2020, BI had cut the BI 7-day Reverse Repo Rate (the policy rate) by 100 basis points (bps) in total to $4.00 \%$. BI reduced the IDR minimum reserve requirement (IDR GWM) ratio for conventional banks by 200 bps to $3.5 \%$ and for sharia banks by 50 bps to $3.5 \%$ (effective from 1 May 2020), and implemented various other macroprudential policies. BI cut the FX GWM from 8 to 4\%, effective from 16 March 2020. BI has also conducted a quantitative easing policy to inject liquidity in the economy, which from the beginning of the year until the end of September 2020 had amounted to IDR666 trillion. Perppu No. 1/2020 allows BI to purchase SBN instruments in the primary market through private placement, where previously BI could only buy SBN instruments in the secondary market. On 6 July 2020, BI and the government announced a burdensharing scheme where BI will help partially to finance the government budget deficit by buying the SBN instruments and bearing some portion of interest payments for them.

The COVID-19 pandemic has affected Indonesia's financial market and monetary policy dynamics. However, studies on the impacts of COVID-19 on Indonesia's economy and Indonesian authorities' policy responses mostly focus on the real sector of the economy and the fiscal policy aspect. These include studies by Susilawati et al. (2020), who find that the household sector is the most affected by the pandemic; Surhayadi et al. (2020), who discuss the increasing poverty rate due to the pandemic; and Hasibuan et al. (2020), who discuss the fiscal policy measures to cope with the pandemic.

In this paper, we investigate the impacts of the COVID-19 pandemic on Indonesia's financial markets and monetary policy dynamics. The paper proceeds as follows. Section 2 briefly discusses related literature on the impacts of COVID-19 on the economy and financial markets, and policy responses in various countries. Section 3 describes Indonesia's financial market dynamics during the pandemic. 
Section 4 discusses BI's monetary policy responses. Section 5 elaborates regression models that examine the impacts of the COVID-19 pandemic on the financial markets and monetary policy dynamics. Section 6 concludes.

\section{Related Literature}

Recent economic studies on the COVID-19 pandemic mostly fall into the following categories: (1) analysis of the economic impacts, transmission channels of such impacts, and economic costs of the pandemic; (2) assessment of policy options to mitigate the pandemic impacts on the economy; and (3) analysis of the impacts of the pandemic on the financial system at the global, regional, and national levels. Many of these studies trace past pandemics to find similarities with the ongoing COVID-19 pandemic.

In general, pandemics impact the economy through both the supply and demand sides of each country's economy and can be transmitted across countries via trade, financial, and travel/tourism channels. Correia et al. (2020) show that the downturn in the US economy during the 1918 Great Influenza pandemic was driven by both the demand and supply sides. Verikios et al. (2011) find that the more integrated into the world economy a region is, the more likely it will be affected by a pandemic. They also find that global economic activity will be more strongly affected by a pandemic with a high infection rate rather than a high virulence rate.

Since the COVID-19 pandemic is still far from over, current estimates of the economic costs of this pandemic are only preliminary and will continue to change. Barro et al. (2020) suggest that the 1918 Great Influenza pandemic can provide a plausible worst-case scenario for mortality rates and economic contraction on the ongoing COVID-19 pandemic. Taking COVID-19 into account, in April 2020 the International Monetary Fund (IMF) (2020a) changed its global GDP growth projection for 2020 from $3.3 \%$ before the pandemic to $-3.0 \%$. In October 2020 (IMF, $2020 \mathrm{~b}$ ), the IMF revised its forecast for 2020 global GDP growth to $-4.4 \%$. The Asian Development Bank (ADB) (2020) estimates that the economic losses of COVID-19 could reach $6.4 \%$ of global GDP under the 3-month containment scenario and $9.7 \%$ of global GDP under the 6-month containment scenario.

There is some degree of disagreement among researchers concerning the best policy option to mitigate the health and economic impacts of COVID-19. For instance, Acemoglu et.al. (2020) and Boissay et al. (2020) suggest lockdown, while Ozili and Arun (2020) suggest instead a restriction on internal movement. Pindyck (2020) suggests that the strategy of reducing the "reproduction number' R0 decreases the number of deaths but extends the duration of the pandemic, increases the economic cost, and raises the possibility of a second wave of the pandemic. Kohlscheen et al. (2020) expect the reduction of GDP due to confinement measures to drag on over several quarters.

Studies on the impacts of COVID-19 on the financial system tend to cover the following areas, which often overlap in the analysis: (1) the banking system and the credit market; (2) the debt securities market; (3) stock markets; and (4) the foreign exchange market. Studies on the impact of COVID-19 on emerging market 
economies (EMEs) financial markets mostly analyze the dynamics of cross-border capital flows from the advanced economies to EMEs during the pandemic and their impacts on the EMEs' financial system stability.

Several studies examine the impacts of COVID-19 on the banking system. Aldasoro et al. (2020) see that all banks in advanced economies and EMEs are affected by the pandemic and expect the credit market to remain tight despite the recovery in the financial markets. Ari et al. (2020) see that the EU banking system is currently in a better position to cope with the non-performing loan (NPL) risk stemming from the pandemic compared to its position in the 2008 global financial crisis. Perkins et al. (2020) see that the US banking industry is still in a sound position but needs to anticipate the risk of loan defaults from banks that have a high concentration of loans in their portfolios.

A study by Rismanchi (2020) on banking regulatory measures by 33 jurisdictions and authorities to respond to the pandemic shows that advanced economies tend to use a combination of measures on capital, provisioning, liquidity, timetables, and other regulations. EMEs tend not to issue or only issue fewer regulatory measures on capital. Indonesia does not use regulatory measures on capital and provisioning but uses liquidity and other types of measures.

Hördahl and Shim (2020) investigate the impacts of the COVID-19 pandemic on relations between bond portfolio outflows and exchange rates, and between bond outflows and long-term interest rates in 19 EMEs. Bond portfolio outflows from the EMEs are typically related to these countries' currency depreciation and long-term interest rates, but it is difficult to determine directions of causality. The COVID-19 pandemic affirms this relationship.

Hofmann et al. (2020a, 2020b) suggest that borrowing through domestic currency bonds has not insulated EMEs from the financial shock caused by COVID-19. Many governments in EMEs seek to attract foreign investors to buy debt securities in local currencies, as this strategy can help to reduce their reliance on international bank lending that contains a double mismatch risk (i.e., currency and maturity mismatches), as seen before the 1990s EMEs' financial crisis. Yet, this strategy exposes EMEs to the risk of capital outflows amid global financial shocks, as seen in the case of COVID-19.

Beirne et al. (2020, 2021) examine the impacts of fiscal policy stimulus packages and quantitative easing policies in 38 economies, finding that these policies have helped to restore overall investor confidence by reducing bond yields and boosting stock prices. They also find that the impacts of COVID-19-related quantitative easing measures by central banks in advanced countries were extended to EMEs and helped to stabilize capital flow dynamics in these countries.

Haroon and Rizvi (2020) examine the impacts of the COVID-19 pandemic on liquidity in 23 EMEs. They find that a decreasing (increasing) trend in the number of confirmed cases is associated with improving (deteriorating) liquidity in financial markets. They also find that policy interventions in terms of restrictions on movement and businesses are associated with improved liquidity. They conclude that flattening the curve of coronavirus infections helps reduce uncertainty among investors.

Ruiz and Villafranca (2020) compare the effects of four transmission channels of the COVID-19 pandemic on EMEs: (1) trade (measured as exports to the US, 
the EU, and the People's Republic of China as a percentage of GDP); (2) tourism (contribution of the tourism sector as a percentage of GDP); (3) hydrocarbons (net energy exports as a percentage of GDP); and (4) containment (taken from the University of Oxford's COVID-19 government response stringency index). In the case of Indonesia, the impacts of COVID-19 are mainly transmitted through the containment channel.

García-Herrero and Ribakova (2020) see that EMEs have limited policy options or policy room to cope with shrinking global liquidity. This is shown by less aggressive policy responses by central banks in EMEs than in their counterparts in the West since their respective currencies have weakened, thus increasing the costs of USD liabilities. García-Herrero and Ribakova suggest the IMF plays its role as the lender of last resort for EMEs but with some improvements to its current lending practices to make the lending more effective.

Esteves and Sussman (2020) suggest that the COVID-19 pandemic has only limited explanatory power over financial stress in EMEs. While, in the beginning, EMEs' economies were penalized more than advanced economies, EMEs began to benefit from the rebound in global markets despite the increasing death rates in their territories. Moreover, EMEs seem to be less penalized in this pandemic than in the 2008 global financial crisis.

\section{Indonesia's Financial Markets Dynamics Amid the COVID-19 Pandemic}

This section discusses the dynamics of Indonesia's IDR interbank money market, the USD interbank money market, conventional SBN markets, the stock market, and the USD/IDR foreign exchange (FX) market amid the COVID-19 pandemic. The SBN instruments are differentiated between conventional debt securities (SUN) and sharia debt securities (SBSN). The SUN instruments can be differentiated further based on their tenor: (1) SUN instruments with a maximum tenor of 1 year (the SPN); and (2) SUN instruments with a tenor of more than 1 year (the ON). We do not discuss SBSN instruments as the SBSN markets have different rules from those in the SUN markets.

The IDR interbank money market rates (JIBORs) moved in line with the BI rate (Fig. 1). All JIBORs declined when the BI 7-day Reverse Repo Rate was cut in February, March, June, and July 2020. From late June 2020, the overnight JIBOR fell more than other JIBORs with longer tenors. Liquidity in the banking system rapidly increased from late June 2020 as the government began placing a large number of funds in selected state-owned and private banks to be channeled to the real sector of the economy. As the fund needs to be quickly channeled to accelerate Indonesia's economic recovery, most of the fund is placed in overnight government accounts in these banks, causing a rapid decline of the overnight JIBOR.

The average USD interbank money market rates moved more dynamically than the JIBORs (Fig. 2). While these rates had declining trends from the beginning of the year until the end of September 2020, they did not move in tandem with the BI 


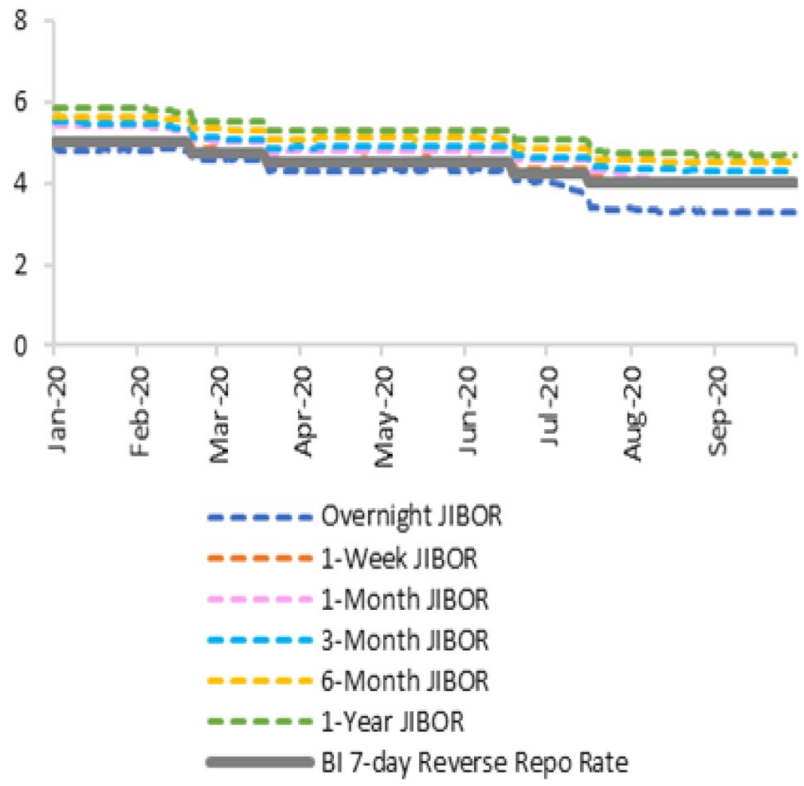

Fig. 1 IDR interbank money market rates and BI 7-day Reverse Repo Rate (\%). Souce: Bloomberg

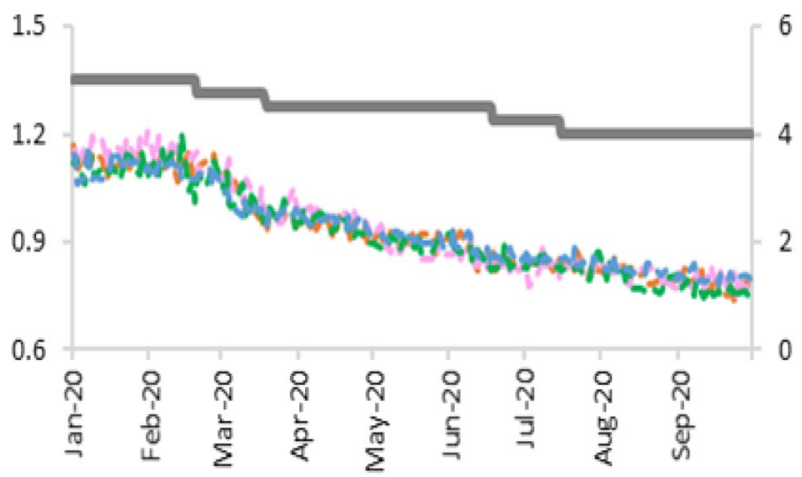

$$
\begin{gathered}
----- \text { Average 1-Month USD Interbank MM Rate } \\
---- \text { Average 3-Month USD InterbankMM Rate } \\
---- \text { Average 6-Month USD Interbank MM Rate } \\
----- \text { Average 1-Year USD Interbank MM Rate } \\
\text { BI 7-day Reverse Repo Rate (RHS) }
\end{gathered}
$$

Fig. 2 Average USD Interbank Money Market Rates and BI 7-day Reverse Repo Rate (\%). Souce: Bloomberg 


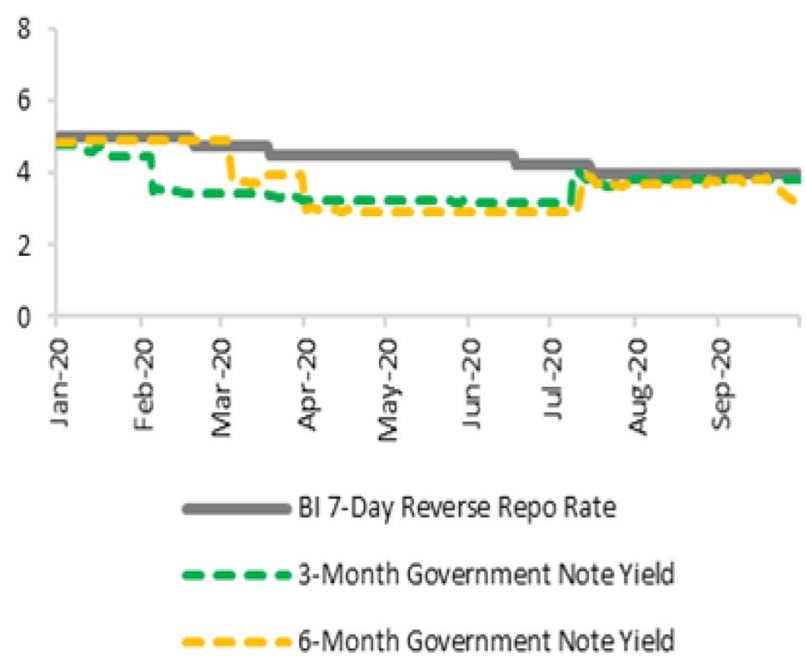

Fig. 3 Short-term SUN (SPN) and BI 7-day Reverse Repo Rate (\%). Souce: Bloomberg

7-day Reverse Repo Rate as they were also affected by the movement of the IDR exchange rate against the USD.

Figure 3 shows rather diverse movements of the 3-month and 6-month SPN yields in February and early March 2020. The yields of the SPN instruments did not always move in the same direction as the BI 7-day Reverse Repo Rate. The SPN instruments market is less liquid than the markets for SUN instruments with longer tenors; hence the demand and supply interactions in this market are less responsive to policy rate change and other macroeconomic variables than in the longer-tenor SUN markets.

Figures 4 and 5 show the dynamics of the medium and long-term SUN instruments, respectively. While the 1-year SPN is categorized by Indonesian law as a short-term government bond, we categorize it as a medium-term bond in the regression models due to the co-movement of the one-year SPN yield with the yields of 2-year, 3-year, 5-year, and 7-year SUN instruments rather than with the shorter tenor SPN yields.

The yield of the medium and long-term SUN instruments moved in the opposite direction to the BI 7-day Reverse Repo Rate in March 2020. The expectation factor played its role here. There was concern among foreign bond investors over the possibility of the government raising the budget deficit target to launch the third fiscal stimulus package and uncertainty about the size of increases in the budget deficit and SBN supply. As a result, foreign investors reduced their SBN holdings and caused the SBN yields to increase.

The yield of the medium and long-term SUN instruments began to stabilize in April 2020, presumably because the Indonesian government had finally announced the PSBB policy and the fiscal stimulus package on 31 March 2020. Despite the rising budget deficit, the announcement of the third fiscal policy package helped to reduce concerns among investors as it gave clarity about the government's 


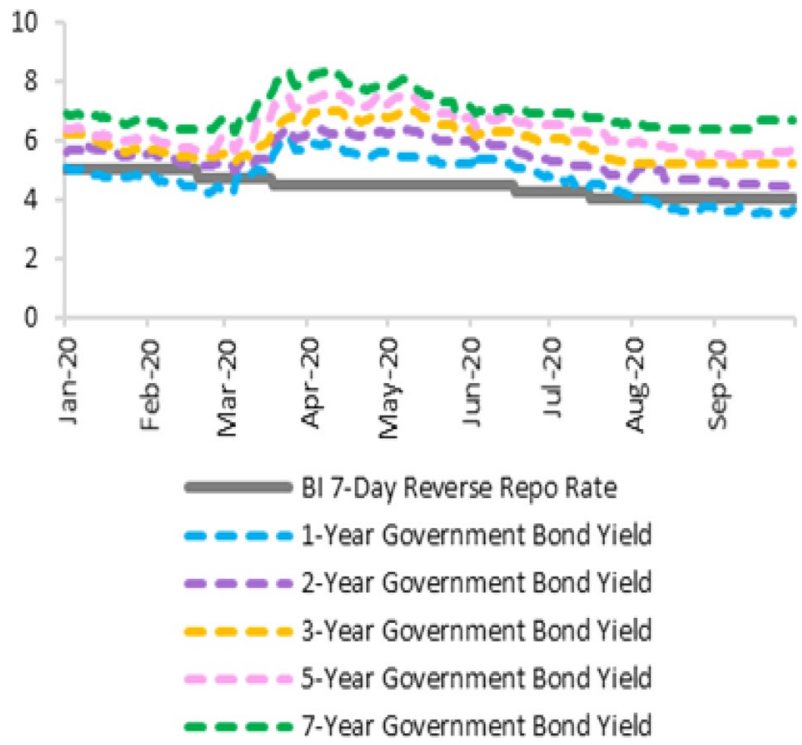

Fig. 4 Medium-term SUN and BI 7-day Reverse Repo Rate (\%). Souce: Bloomberg

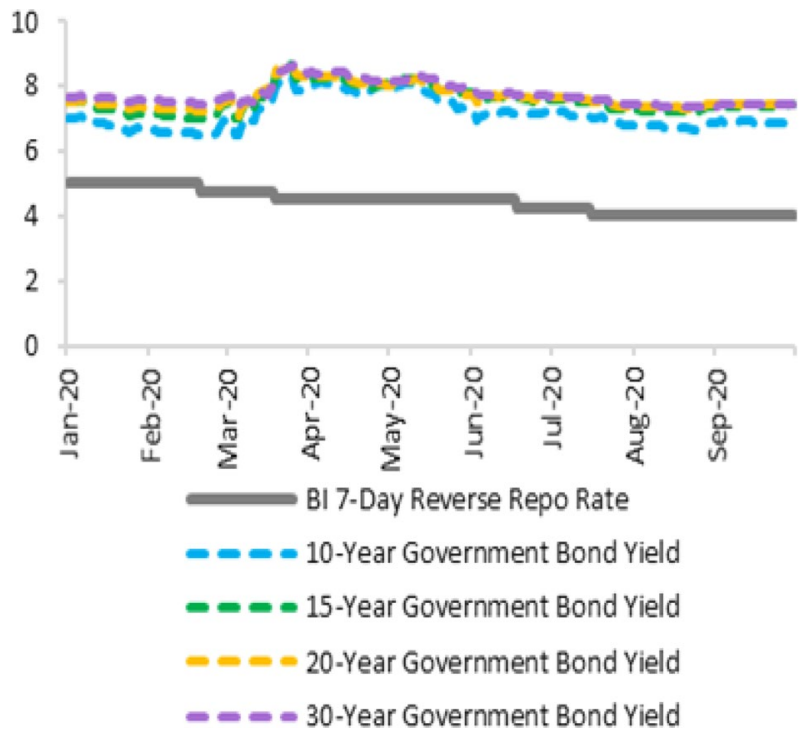

Fig. 5 Long-term SUN and BI 7-day Reverse Repo Rate (\%). Souce: Bloomberg

policy direction to cope with the pandemic and mitigate its negative impacts on the economy.

Figure 6 show the dynamics of the Indonesia Composite Index (JCI) and its sectoral indexes: (a) finance (JAKFIN); (b) construction, property, and real estate 


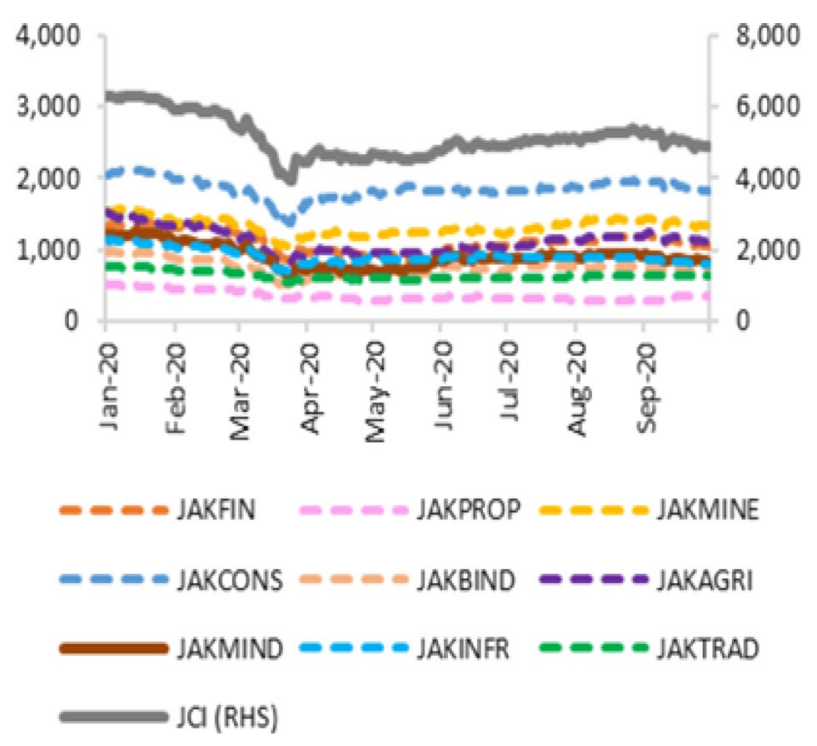

Fig. 6 Indonesia Composite Index (JCI) and Sectoral Indexes. Souce: Bloomberg

(JAKPROP); (c) mining (JAKMINE); (d) consumer goods (JAKCONS); (e) basic industry and chemical (JAKBIND); (f) agricultural (JAKAGRI); (g) miscellaneous industries (JAKMIND); (h) infrastructure, utility, and transportation (JAKINFR); and (i) trade services and investment (JAKTRAD).

The JCI and its sectoral indexes tanked in early and mid-March 2020, largely due to negative sentiment from the major global stock exchanges and news of the COVID-19 outbreak in Indonesia. The JCI and its sectoral indexes began to rebound (despite not yet returning to the pre-pandemic level) in late March 2020 amid an improvement in investors' sentiment. As Esteves and Sussman (2020) suggested that EMEs were less penalized during the COVID-19 pandemic compared to the 2008 global financial crisis, so the decline in the JCI during the pandemic was much smaller than its decline in the 2008 crisis. The JCI fell by $38 \%$ from the beginning of the year 2020 to the trough of the decline on 24 March 2020, compared to its $147 \%$ decline from the beginning of the year 2008 until its trough on 28 October 2008.

Figure 7 displays the movement of the USD/IDR spot rate, the one-month BI domestic non-deliverable forward (DNDF) rate, and the three-month DNDF rate during the pandemic. IDR underwent rapid depreciation in the spot market from 14,318 per USD at the end of February 2020 to 16,310 per USD at the end of March amid capital outflows from the SUN instruments and the stock market. Substantial pressures on the IDR caused BI FX swap hedging transaction rates to increase sharply in the second week of March 2020 (Fig. 8). The USD/IDR begin to rebound in early April 2020 as the global financial market began to stabilize and as the Indonesian government announced the Perppu on 31 March 2020.

Despite the COVID-19 pandemic, total ownership of the tradable SUN instruments increased from IDR 2267 trillion at the beginning of the year to IDR 2660 


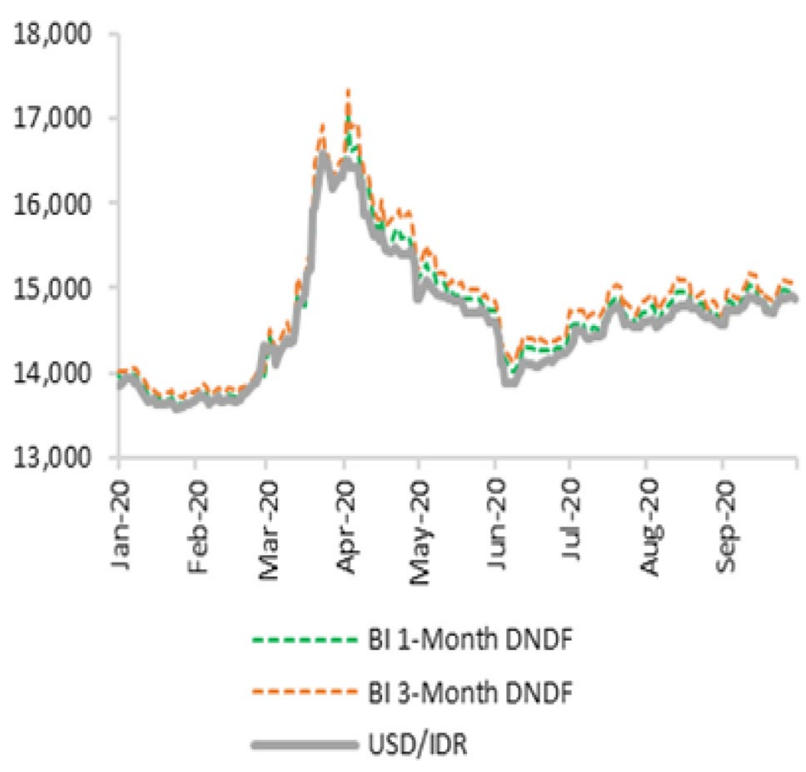

Fig. 7 USD/IDR Spot and DNDF Rates. Souce: Bloomberg

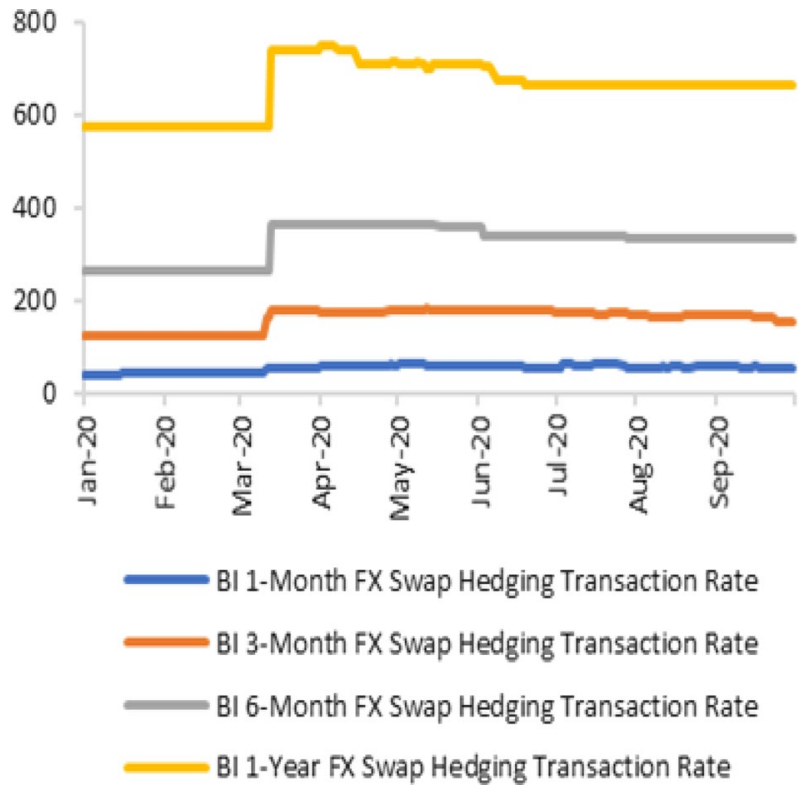

Fig. 8 BI FX Swap Hedging Transaction Rates (Swap Points). Souce: Bloomberg

trillion at the end of September 2020. There was a substantial change in the composition of the tradable SUN instrument ownership during the pandemic. Ownership by non-resident (foreign) investors (which are not foreign governments or central 
banks) declined from $37.4 \%$ of total tradable SUN instruments at the beginning of the year to $27.3 \%$ of the total at the end of September 2020. In contrast, the share of ownership by conventional banks increased from $19.3 \%$ of the total at beginning of the year to $38.1 \%$ at the end of September 2020. As demand for banking credit slowed, banks increased their fund placement on the SUN instruments. BI also increased its ownership of tradable government SUNs. Part of the increase in banks' ownership of tradable SUN came from BI's monetary operation.

The composition of stock ownership in the Indonesia Central Securities Depository (KSEI) has also changed during the pandemic. The total value of stocks deposited in the KSEI fell from IDR 3248 trillion at the end of February 2020 to IDR 2727 trillion at the end of March 2020. Both local and foreign ownership of Indonesian stocks fell in March 2020 before rebounding in April 2020, and stood at IDR 3,023 trillion at the end of September 2020. There was a substantial change in the composition of stock ownership. At the end of January 2020, foreign investors held $52.5 \%$ of the total value of stocks in the KSEI, while local investors held $47.5 \%$. At the end of September 2020, local investors held 51.7\% versus foreign investors' $48.3 \%$.

The market size of the SBI instruments is much smaller compared to those of the SUN markets and the stock market. There was a substantial decline in the number of SBIs issued by BI, from IDR 35.4 trillion at the end of February 2020 to IDR 9.3 trillion at the end of July 2020. At the end of July 2020, around $90 \%$ of the SBI instruments were owned by banks. BI reduces the frequency of SBI auctions and uses the SUN instruments more often for its monetary operations.

\section{Monetary Policy Responses}

This section explores BI's three main policy responses to protect the Indonesian economy from the negative impacts of the COVID-19 pandemic: (1) BI 7-day Reverse Repo Rate cuts; (2) BI's monetary operations; and (3) the cut in minimum requirement (GWM) ratios for conventional and sharia banks.

BI cut the BI 7-day Reverse Repo Rate by 25bps each in February, March, June, and July 2020 (Fig. 9), and it cut the BI lending facility and the BI deposit facility by the same magnitude as the policy rate. BI expected these cuts to help to promote banking credit growth to stimulate the economy. These BI 7-day Reverse Repo Rate cuts may not be optimal if the demand side of the economy (particularly household consumption) is still weak, as weaker demand for goods and services causes real sector investors to reduce their borrowing from banks. Indonesia's demand-side has weakened since the end of the commodity price boom in 2012. The economy grew by 5.0\% on average from 2015 to 2019, compared to 5.6\% from 2009 to 2014. Although BI had already cut the BI 7-day Reverse Repo Rate by 100 bps to $5.00 \%$ in 2019, banking credit growth slowed to $6 \%$ (from 12\% in 2018) and GDP growth slowed to $5.0 \%$ (from $5.2 \%$ in 2018). The COVID-19 pandemic has worsened the demand-side problem.

Figure 10 displays the composition of the monetary base (reserve money) from the beginning of the year to the end of September 2020. Currency in circulation 


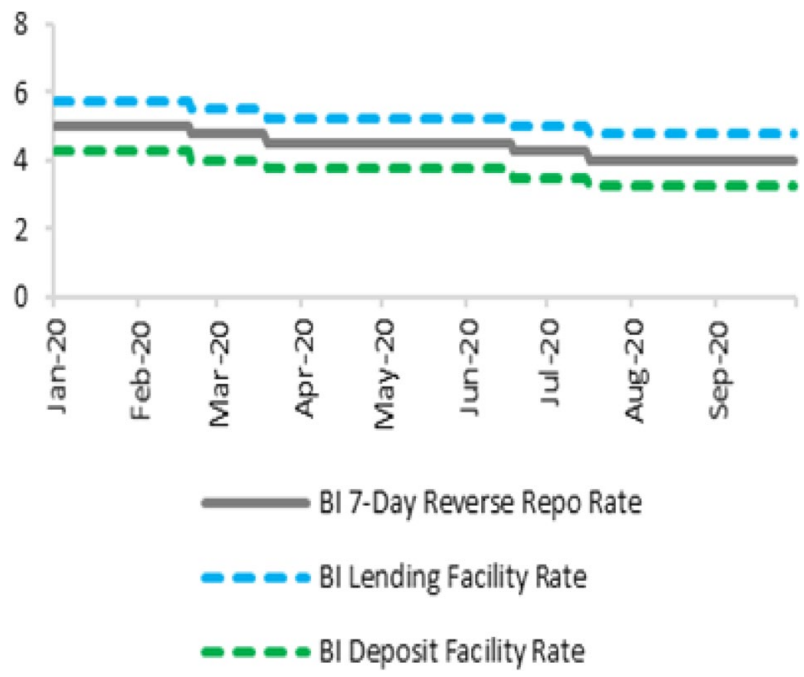

Fig. 9 BI 7-Day Reverse Repo, BI Lending Facility, and BI Deposit Facility Rates (\%). Souce: Bloomberg

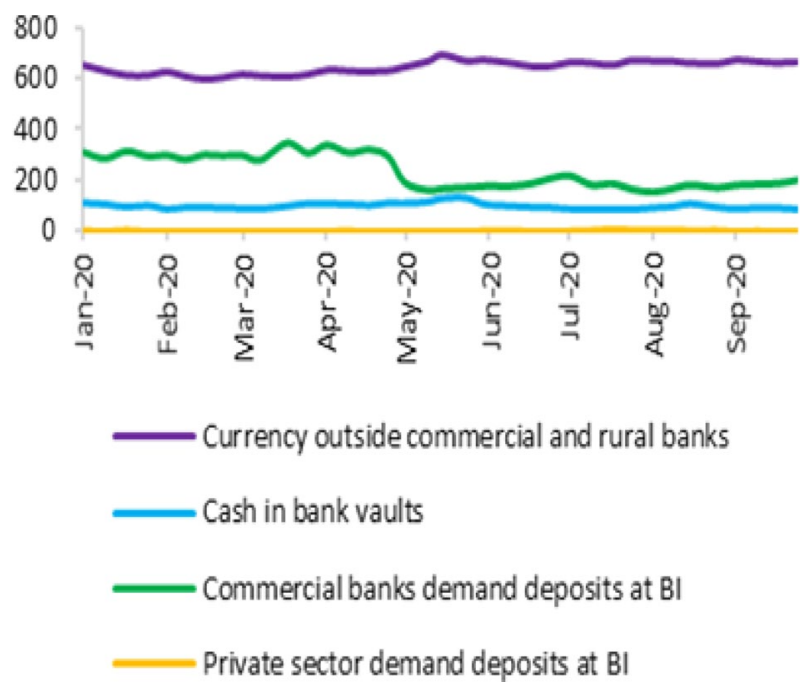

Fig. 10 Monetary Base Composition (IDR trillion). Souce: Bank Indonesia

comprises currency outside commercial and rural banks and the cash in bank vaults. There has been an increasing trend for currency outside commercial and rural banks since early March 2020, which may indicate cash hoarding by households as a precautionary measure in the time of the pandemic. BI's policy to cut the IDR GWM ratios has caused the total bank deposits in BI to fall substantially in early May 2020. 


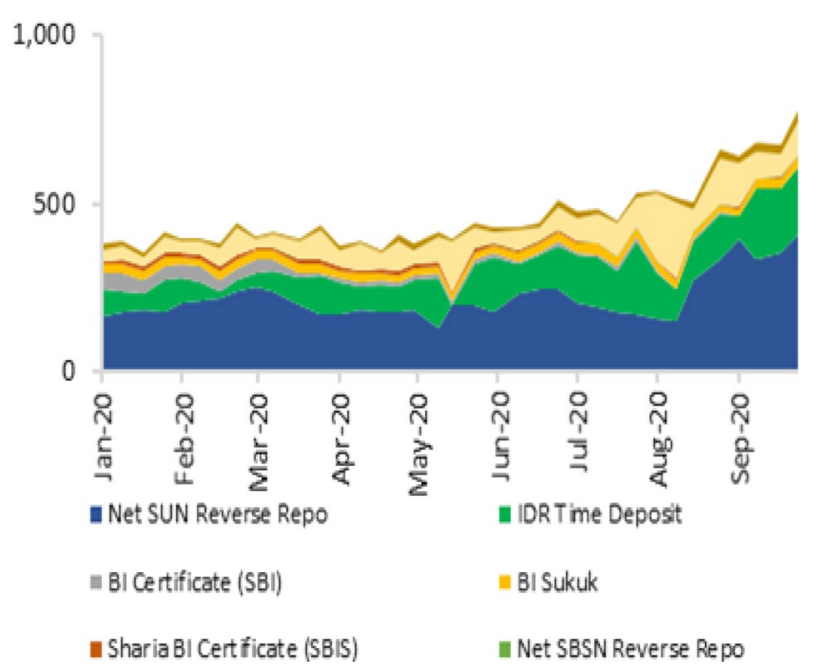

Fig. 11 BI's IDR Monetary Operation Balance (IDR trillion). Souce: Bank Indonesia

Figure 11 shows BI's IDR monetary operation balance from early in the year to the end of September 2020. The components of BI's monetary operation balance are: (1) BI certificates (SBI); (2) IDR time deposits placed by banks in BI; (3) SUN reverse repo; (4) SUN repo; (5) sharia BI certificate (SBIS); (6) BI sukuk; (7) SBSN reverse repo; (8) SBSN repo; (9) BI standing facility; and (10) BI sharia standing facility. The net SUN reverse repo instrument in the Figure is obtained by subtracting the SUN repo from the SUN reverse repo. Likewise, the net SBSN reverse repo is obtained by subtracting the SBSN repo from the SBSN reverse repo. Components (1)-(8) make up BI's total open market operation (OMO) balance, while components (1)-(10) make up BI's total monetary operation balance. An increase (decrease) in BI's monetary balance indicates that BI conducts a net liquidity absorption (injection) operation.

While running monetary policy easing to cope with the pandemic, BI is still checking inflationary pressures by absorbing the excess liquidity in the economy. Figure 11 shows that BI's monetary operation balance has been increasing since late April 2020. IDR liquidity in the economy has been ample due to the following factors: (1) the IDR GWM ratio cut from 1 May 2020; (2) the retrieval of IDR deposits by banks to meet their customers' demand for cash during Ramadan in May 2020; (3) the government placement of funds in selected banks from late June 2020.

BI cut the FX GWM from 8 to 4\% in March 2020 to increase USD liquidity in the banking system, as banks needed to meet the demand for USD from their clients. Yet BI's USD interbank money market balance increased in March 2020, as BI issued more USD term deposits to absorb USD and strengthen its FX reserves amid strong pressures on the IDR (Fig. 12). BI used its FX reserves to stabilize the IDR FX market to reduce IDR volatility. BI's USD interbank OMO balance fell in April 2020 as pressures on the IDR receded; it gradually increased from May 2020, before falling substantially in September. 


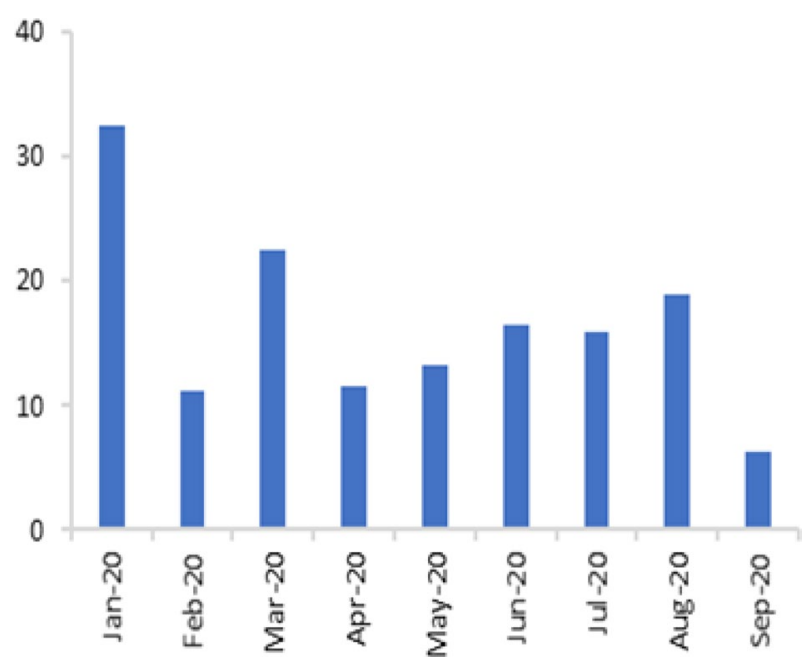

Fig. 12 BI's USD Interbank Money Market OMO Balance (USD billion). Souce: Bank Indonesia

\section{COVID-19 Impact on Indonesia's Financial Markets and Monetary Policy Dynamics}

\subsection{Model Specifications}

We develop four pooled/panel models to examine the impacts of monetary policy instruments on Indonesia's financial markets: (1) the IDR interbank money market (Model 1); (2) the USD interbank money market (Model 2); (3) the government IDR conventional debt securities (SUN) market (Model 3); and (4) the stock market (Model 4). We estimate these four models using two different methods: (1) the pooled Estimated Generalized Least Squares (EGLS) or also known as the Feasible Generalized Least Squares (FGLS) with the cross-section fixedeffects and cross-section weights; and (2) the panel Autoregressive Distributed Lag (ARDL) method. ${ }^{1}$ We compare the estimates from the two methods to check the robustness of the results. We also construct a time-series model for the IDR

\footnotetext{
${ }^{1}$ We use the method of pooled EGLS with the cross-section fixed-effects and cross-section weights because it can tackle the problems of serial correlation and heteroskedasticity in the pooled/panel data structure. Running the model using the panel EGLS instead of pooled EGLS produces the same results. We select the panel ARDL rather than the panel Generalized Methods of Moments (GMM) method because the ARDL method is more appropriate for models with the number of time-series observations larger than the number of cross-sections. There are two main limitations of the panel GMM method for estimating this type of panel data structure: (1) it only captures the dynamics of the short-run and ignores the long-run relationship since the estimator is designed for a small-time span and may produce spurious results instead of long-run equilibrium (Asteriou et al., 2021; Christopoulos \& Tsionas, 2004); and (2) the GMM estimator may suffer from an autocorrelation problem in the residuals of the first-difference estimation (Asteriou et al., 2021). The ARDL estimation method can tackle these two issues.
} 
spot exchange rate against the USD (Model 5) and use the Ordinary Least Square (OLS) and the Error Correction Model (ECM) methods for estimation.

Three policy instruments form the main interests of our study: (1) the BI 7-day Reverse Repo Rate (BI7D); (2) the minimum reserve requirement (GWM) ratios for conventional banks (i.e., the IDR_GWM and the FX_GWM ratios); and (3) the suitable BI's monetary operations balance. The BI7D is stated as a 1-day lag variable in Models 1, 2, 3, and 4 since the announcement of this policy rate comes in the evening and thus starts to impact the financial market the following day. The same-day value of BI7D is used in the OLS estimation for Model 5, as the FX market operates $24 \mathrm{~h}$.

The suitable monetary operation type for Model 1 is BI's IDR interbank money market open market operation (MM_OMO) which uses BI certificates (SBI), banks' IDR time deposits in BI, and BI deposit certificates. The suitable monetary operation type for Model 2 is BI's foreign exchange (FX) interbank money market OMO (FX_MM_OMO) that uses USD term deposits. The suitable monetary operation for Model 3 is BI's open market operations in the SUN markets that use the SUN instruments (SUN_OMO). The suitable operation type for Model 4 is BI's total IDR monetary operation (TMO) that comprise the OMOs and other operations.

We use three COVID-19-related control variables in all models: (i) the COVID-19 dummy (COVID); (ii) the PSBB dummy; and (iii) the fiscal policy package dummy (FISPACK). In addition to these COVID-19-related control variables, each model can have other control variables.

The COVID variable has a value of 1 for every date from 30 January 2020 (the day when the WHO declared a global emergency status for the COVID-19 outbreak) until 30 September 2020 (the last observation date in our study), and 0 otherwise.

The PSBB variable is to differentiate between the period before the government imposed large-scale social distancing $(\mathrm{PSBB}=0)$, the period when social distancing was imposed $(\mathrm{PSBB}=1)$, and the period when the government officially ended social distancing and replaced it with the 'new normal' policy $(\mathrm{PSBB}=2)$.

The FISPACK variable differentiates between the period before the announcement of the first fiscal package (FISPACK $=0$ ), the period between the announcement of the first fiscal policy package and the announcement of the second package (FISPACK $=1)$, the period between the announcement of the second package and the announcement of the third package (FISPACK $=2$ ), and the period from the announcement of the third fiscal package to 30 September 2020 (FISPACK=3).

We introduce the following interaction variables to the models to pin down the impact of the COVID-19 pandemic on the relationships between monetary policy instruments and the dependent variable in each model: (1) an interaction variable between the BI7D and the COVID; (2) an interaction variable between the GWM and the COVID; and (3) an interaction variable between the BI monetary operation and COVID. Each of the interaction variables is obtained by multiplying the respective monetary policy instrument variable with the COVID dummy variable.

The generic form of regression equation in Models 1, 2, 3, 4, and 5 is stated as: 


$$
\begin{aligned}
Y_{t}= & \beta_{0}+\beta_{1} \text { GEN }_{\text {CON }_{i, t \text { or } t-1}}+\beta_{2} \text { COVID }_{\text {CON }_{j, t}}+\beta_{3} \text { MPOL }_{k, \text { tort }-1} \\
& +\beta_{4} \text { MPOL_COVID } \\
k, \text { tort }-1 & +\varepsilon_{t}
\end{aligned}
$$

where $\mathrm{Y}$ is the dependent variable; $\beta_{0}$ is the constant term; GEN_CON is a set of general control variables that affect the dependent variable; COVID_CON is a set of control variables that are specifically related to the COVID-19 pandemic; MPOL is a set of BI's monetary policy instrument variables; MPOL_COVID is a set of interaction variables between the monetary policy and the COVID dummy variable; and $\varepsilon$ is the error term. Indexes $\mathrm{i}, \mathrm{j}$, and $\mathrm{k}$ are indexes for variables in the model, and $\mathrm{t}$ is the time index; $\beta_{1}, \beta_{2}, \beta_{3}$, and $\beta_{4}$ are coefficient matrixes for the respective variables in the models. Table 1 displays the list of variables in the models.

The dependent variable in Model 1 is IDR interbank money market rates, which are JIBORs of various tenors. The regressors are listed in Table 1. The JIBORs data comprise the following tenors: (1) overnight, (2) 1 week, (3) 1 month, (4) 3 months, (5) 6 months, and (6) 1 year.

The dependent variable in Model 2 is the average USD interbank money market rates. The regressors are listed in Table 1. The pooled/panel average USD interbank money market rate data comprise the following tenors: (1) 1 month, (2) 3 months, (3) 6 months, and (4) 1 year.

We run separate regressions in Model 3 for the three groups of SUN instruments: (a) Model 3A for the short-term SUN (i.e., the SPN) group; (b) Model 3B for the medium-term SUN group; and (c) Model 3C for the long-term SUN group. The dependent variables in Models 3A, 3B, and 3C are the respective SUN yields. The regressors are listed in Table 1. The SPN group comprises 3-month and 6-month SPN instruments. The medium-term SUN group comprises 1-year, 2-year, 3-year, 5-year, and 7-year SUN instruments. The long-term SUN group comprises the 10-year, 15-year, 20-year, and 30-year SUN instruments.

The relevant US Treasury debt securities (UST) for the SUN groups in the regressions are: (1) 3-month UST for the SPN group; (2) 5-year UST for the medium-term SUN group; and (3) 10-year UST for the long-term SUN group. The yield of the UST variable is stated as a one-day lag variable as Indonesia's financial markets operate after the US markets close.

The dependent variable for Model 4 is the sectoral indexes in the Indonesia Stock Exchange. The regressors are listed in Table 1. The Chicago Board Options Exchange's Volatility Index (the VIX index), with a 1-day lag, is incorporated into the model to control the impact of global stock market volatility stemming from US stock market volatility. The US S\&P 500 index (with a 1-day lag), Singapore's Strait Times index, and China's Shanghai Composite index are incorporated in the model to control the impacts of major stock market indexes on the Indonesia Stock Exchange.

The dependent variable for Model 5 is the USD/IDR spot exchange rate. The regressors are listed in Table 1. The USD currency index (the DXY index) is incorporated into the model to control the indirect impact of USD valuations against major currencies on the IDR. Model 5 does not include BI's FX daily intervention variable because due to the unavailability of public data. 


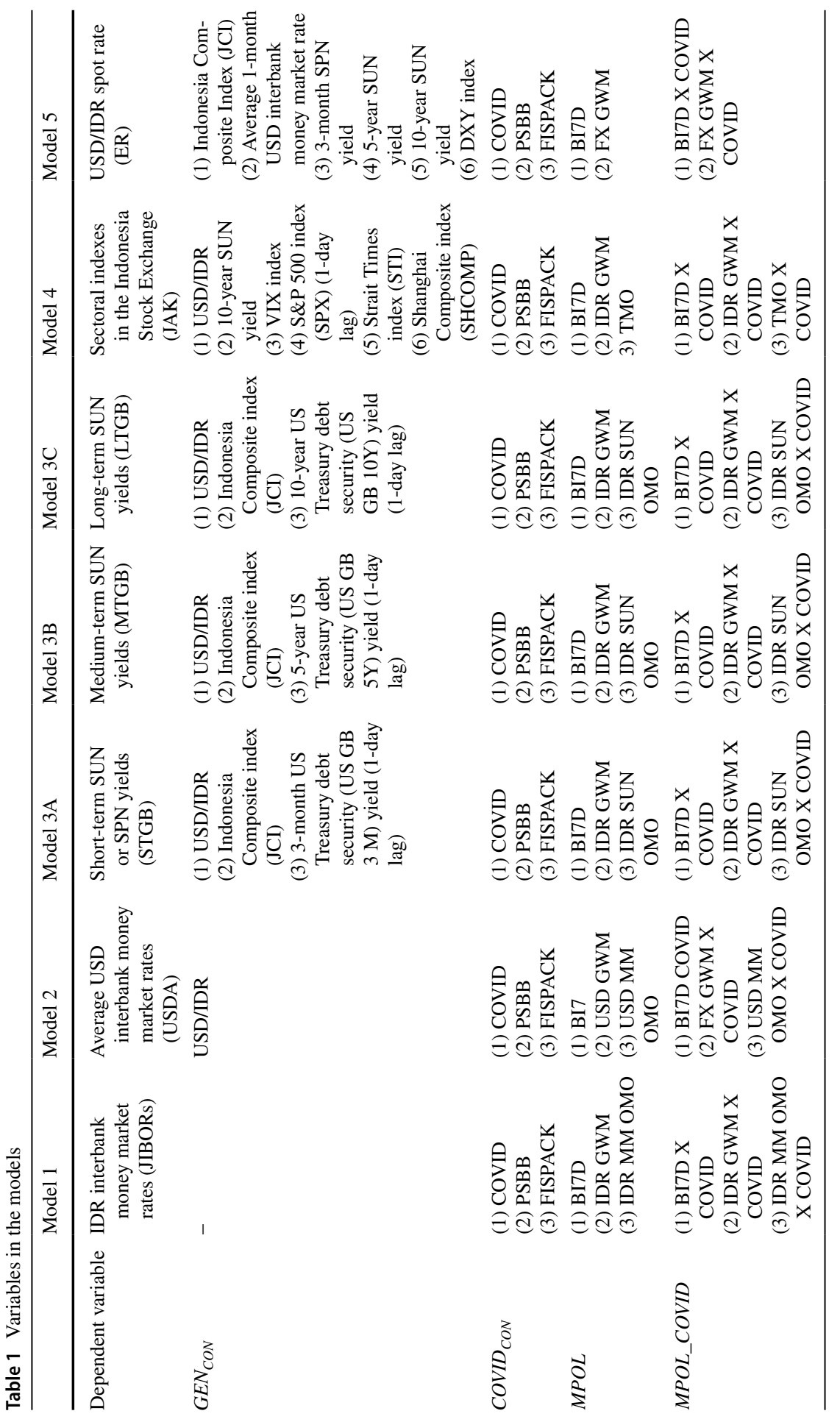


The sample range in our models covers all working days from 1 January 2017 to 30 September 2020. The data for our study are taken from BI's website, the Ministry of Finance's website, Bloomberg, the CEIC, and Indonesia's major media. We use the quadratic interpolation method in the EViews 12 software to convert the weekly data on BI's monetary operation balance into daily data. ${ }^{2}$ This method is better suited to situations where relatively few data points are being interpolated and the source data is fairly smooth, as we have in our data. Several studies have used the quadratic interpolation method, such as in Cheung et al. (2010), Patra and Ray (2010), and Beirne et al. (2021).

All non-dummy variables in the pooled EGLS estimation for Models 1, 2, 3A, $3 \mathrm{~B}, 3 \mathrm{C}$, and 4 and the OLS estimation for Model 5 are stated as day over day $(\mathrm{d} / \mathrm{d})$ differences to make them stationary. The Augmented Dickey-Fuller and the PhillipPeron tests at the 5\% significance level confirm the stationarity of all the variables at the first-order differencing.

We use the cross-section fixed effects and cross-section weights for the pooled EGLS estimation. The redundant fixed effect tests rejected the null hypothesis of fixed effect redundancy in Models, 1, 2, 3, and 4 at the 5\% significance level, which confirms that we should include the fixed effects in our models. ${ }^{3}$ The cross-section weighting in Models 1, 2, 3, and 4 is used to treat the heteroskedasticity problem. We add appropriate autoregression (AR) terms to treat serial correlation problems in the pooled EGLS estimations for Models 1, 2, 3, and 4.

We conduct the Pedroni (1999) cointegration tests for Models 1, 2, 3A, 3B, $3 \mathrm{C}$, and 4 before estimating the models using the panel ARDL method. The cointegration test results show that each of these models is cointegrated because the null hypothesis of no cointegration is rejected at the 5\% significance level in every model. We conduct the Pesaran and Shin (1995) bounds test for Model 5 before running the estimation. The results show that Model 5 is cointegrated, as the null hypothesis of no cointegration is rejected at the $5 \%$ significance level. Since the model is cointegrated, we use the ECM estimation method for Model 5.

For the panel ARDL estimation in Models 1, 2, 3A, 3B, 3C, and 4 we re-parameterize Eq. (1) to obtain the following equation:

$$
\Delta Y_{i, t}=\underbrace{\theta_{i}\left(Y_{i, t-1}-\beta_{i}^{\prime} X_{i, t}\right)}_{\text {long - run equation }}+\underbrace{\sum_{j=1}^{p-1} \sigma_{i, j} \Delta Y_{i, t-j}+\sum_{j=0}^{q-1} \beta_{i, j}^{\prime} \Delta X_{i, t-j}+\varphi_{i, t}+\varepsilon_{i, t}}_{\text {short - run }}
$$

where

\footnotetext{
2 The quadratic interpolation in the EViews 12 creates a quadratic polynomial by taking sets of three adjacent points from the source series and fitting the quadratic so that either the average or the sum of the high-frequency points matches the low-frequency data actually observed (EViews 12, 2020).

3 The EViews 12 cannot perform the Hausman because the number of variables in our models is larger than the number of cross-sections. Hence, we only use the redundant fixed effect tests.
} 


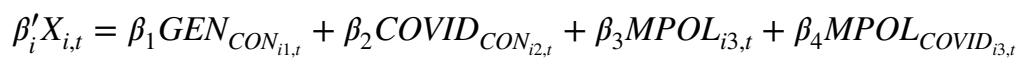

$\theta_{i}=$ adjustment coefficient, where a negative sign of this coefficient implies that the model converges to its long-run equilibrium.

$\Delta Y_{i, t}=$ vector of dependent variable.

$X_{i, t}=$ vector of regressors.

$\Delta=$ differencing operator

$p=$ optimum lag order for the dependent variable.

$q=$ optimum lag order for the regressors.

$\sigma_{i, j}=$ coefficient matrixes for the differenced dependent variable in the short-run equation.

$\rho_{i, j}=$ coefficient matrixes for the differenced regressors in the short-run equation.

$\varphi_{i, t}=$ fixed-effect vector, including a constant and the error correction term (ECT).

$\varepsilon_{i, t}=$ error term vector.

We re-parameterize Eq. (1) to have the following ECM equation for Model 5:

$$
\Delta Y_{t}=\beta_{o}+\sum_{j=0}^{q-1} \beta_{i, j}^{\prime} \Delta X_{i, t-j}+\theta E C T_{t-j}+\varepsilon_{t}
$$

where

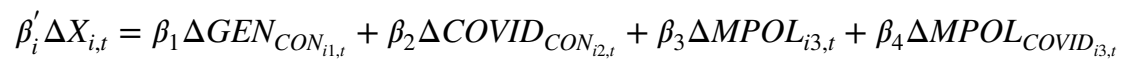

$\Delta Y_{i, t}=$ dependent variable.

$\beta_{o}=$ constant term.

$\beta_{1}, \beta_{2}, \beta_{3}$, and $\beta_{4}$ are coefficient matrixes for the respective variables in the models.

$X_{i, t}=$ vector of regressors.

$\Delta=$ differencing operator

$q=$ optimum lag order for the regressors.

$\theta=$ adjustment coefficient, where a negative sign of this coefficient implies that the model converges to its long-run equilibrium.

$E C T_{t-j}=$ error correction term vector.

$\varepsilon_{i, t}=$ error term.

We apply the Akaike Information Criteria (AIC) to select the optimum number of lags for the panel ARDL and the ECM estimations. The optimum number of lags is the one that produces the lowest AIC value in the model.

We use the correlation matrix to detect the possibility of the multicollinearity problem in all models. ${ }^{4}$ We discard variables that cause the multicollinearity problem from the final models. We discard the interaction variable FX GWM and the

\footnotetext{
${ }^{4}$ We also conduct the variance inflation factor (VIF) tests using the EViews 12 to Model 5 to detect the multicollinearity problem. Variables with the centered VIF values less than 10 do not have a consequential multicollinearity problem (Hair et al., 2005; Mela \& Kopalle, 2002). Nonetheless, the ordinary VIF test in the EViews 12 is not suitable for panel data models, hence we only use the correlation matrix to detect the possibility of multicollinearity problem in Models 1, 2, 3, and 4 .
} 
COVID dummy from Model 2 and Model 5 because this variable creates the multicollinearity problem due to its very strong correlation with the COVID dummy variable (where the correlation coefficient is 0.94).

\subsection{Estimation Results}

In this sub-section, the interpretations of the estimation results are based on the ceteris paribus assumption. The estimation results are displayed in the Appendixes. The results are evaluated at the 5\% significance level (i.e., $\alpha=5 \%$ ).

All models are fit for the pooled EGLS regressions, except for Model 3A. The F-test results reject the null hypothesis of the unfitness of the models at the 5\% significance level, except for Model 3A (where the null hypothesis cannot be rejected). All models are free from the serial correlation problem, as shown by the values of Durbin-Watson (DW) statistics, which are close to 2.

The adjusted R-squared value for the SPN group (Model 3A) is very low, implying that the model does not fit to explain variations in the SPN yields. Moreover, all variables in Model 3A are not statistically significant, except the COVID dummy variable. As discussed in Sect. 3, the illiquid SPN market causes the prices and yields in this market to be less sensitive to changes in macroeconomic and policy variables than those in the longer tenor SUNs.

The pooled EGLS estimation results show that the BI7D variable is statistically significant and has a positive sign in Model 1. The panel ARDL estimation results show that the policy rate has significant short-run and long-run positive relationships with the JIBORs ("Appendix 1"). In other words, the policy rate and the JIBORs move in the same direction, both in the long-run and the short-run. A hike (cut) in the policy rate increases (reduces) the JIBORs. The interaction variable between the BI7D and the COVID dummy is significant and has a positive sign, both in the pooled EGLS and the short-run and long-run panel ARDL estimation results. It implies that the impact of the policy rate on the JIBORs had been greater during the COVID-19 pandemic than in the pre-pandemic period.

The BI7D is significant and has a positive sign in the pooled EGLS estimation result for Model 2. The ARDL estimation results show that the policy rate has a positive long-run relationship with the average rates of the USD interbank money market. It is not significant in the short-run ("Appendix 2"). A hike (cut) in the policy rate increases (reduces) the average rates of the USD interbank money market in the long-run. The interaction variable between the policy rate and the COVID dummy is not significant, both in the pooled EGLS and the panel ARDL estimation results. Hence, there is no significant difference in the impact of the policy rate on the average rates of the USD interbank money market before and during the pandemic.

The pooled EGLS estimation results show that the policy rate is not significant in Models 3A, 3B, and 3C. That said, the panel ARDL estimates show significant long-term positive relationships between the policy rate and the shortterm, medium-term, and long-term SUN yields ("Appendix 3"). A hike (cut) in the policy rate increase (reduces) the short-term, medium-term, and longterm SUN yields in the long-run. The policy rate has a significant short-run 
positive relationship only with the short-term SUN yields. The interaction variable between the policy rate and the COVID dummy is only significant in the short-run ARDL estimation result for the long-term SUN yields. Hence the pandemic temporarily strengthened the impact of the policy rate on the long-term SUN yields.

The pooled EGLS estimation result indicates that the policy rate is not significant in Model 4. The ARDL estimation results show that the policy rate has no significant short-run and long-run relationship with the sectoral indexes of the stock market ("Appendix 4"). The interaction variable between the BI7D and the COVID dummy is not significant, both in the pooled EGLS and panel ARDL results. Hence, there is no significant difference in the relationship between the policy rate and the sectoral indexes of the stock market before and during the pandemic.

The policy rate is not significant in the OLS and ECM estimation results for Model 5. ("Appendix 5"). Hence the policy rate has no significant impact on the USD/IDR exchange rate. The interaction variable between the policy rate and the COVID dummy is significant and has a negative sign in the OLS and the ECM estimation results. It implies that the pandemic weakened the impact of the policy rate on the USD/IDR exchange rate.

The pooled EGLS estimation results show that the IDR_GWM variable is significant in Model 3B and Model 4 but not significant in Models 1, 3A, and 3C. The panel ARDL estimation results for the long-run equation show that the IDR_GWM variable is significant in Model 3B but not significant in Models 1, 3A, 3C, and 4. As for the short-run equation, the ARDL estimation results show that the IDR_ GWM variable is significant in Models 3B, Model 3C, and 4, but not significant in Model 1 and Model 3A.

The pooled EGLS and the short-run panel ARDL estimation results for Model 3B show a significant and negative relationship between the IDR GWM ratio and the yields of the medium-term SUNs. However, the IDR GWM ratio has a positive relationship with the yields of the medium-term SUN in the long-run. ("Appendix 3"). A hike in the IDR GWM ratio reduces the yields of the medium-term SUNs in the short-run but increases the yields in the long-run.

The pooled EGLS and the short-run panel ARDL estimation results show that the interaction variable between the IDR_GWM and the COVID dummy is significant and has a positive sign in Model $3 \mathrm{~B}$, but it is not significant in the long-run. The pooled EGLS show that the interaction variable is not significant in Model 3C. The panel ARDL estimation results for Model 3C show that the interaction variable is significant and has a positive sign in the short-run, but it is not significant in the long-run. We can infer that the pandemic temporarily asserted the impact of the IDR GWM ratio on the yields of the medium-term and long-term SUNs. In the long-run, the pandemic does not significantly affect the relationship between the IDR GWM ratio and the yields of the medium-term and long-term SUNs.

The IDR GWM ratio has a significant impact on the sectoral indexes of the stock market in the short-run but not in the long-run. The estimation results from the pooled EGLS and the short-run equation in the ARDL show negative signs ("Appendix 4"). It implies that the sectoral indexes of the stock market move in the opposite direction of the minimum IDR GWM ratio. 
The interaction variable between the IDR_GWM and the COVID dummy is significant and has a positive sign in the pooled EGLS and the short-run panel ARDL estimation results for Model 4. It is significant but has a negative sign in the long-run ARDL estimation result. Thus, the pandemic temporarily strengthened the impacts of the IDR GWM ratio on the sectoral indexes of the stock market but would weaken these impacts in the long-run.

The FX_GWM variable is not significant in the pooled EGLS and the long-run panel ARDL estimation results for Model 2. It significant in the short-run ARDL estimation results, where the sign is positive in $\mathrm{t}-1$ but negative in $\mathrm{t}-2$ ("Appendix $2 ")$. The variable is significant and has a negative sign in the OLS and in ECM estimation results for Model 5 ("Appendix 5"). We can infer that the FX_GWM has short-run impacts on the USD/IDR exchange rate and the average rates of USD interbank money market rates. The interaction variable between FX GWM and the COVID dummy is discarded from Model 2 and Mode 5 because it creates a multicollinearity problem.

The MM_OMO variable is significant and has a positive sign in the pooled EGLS and the short-run and long-run ARDL estimation results for Model 1 ("Appendix 1"). Although statistically significant, the impacts of the MM_OMO on the JIBORs are marginal (i.e., close to zero). The interaction variable between the MM_OMO and the COVID dummy is significant and has a positive sign in the pooled EGLS, although the impact is marginal. This interaction variable is not significant in the short-run and long-run ARDL estimation results. There is no significant difference or at most a marginal difference in the relationship between BI's IDR interbank money market intervention and the JIBORs before and during the pandemic.

The FX_MM_OMO variable and the interaction variable between the FX_MM_ OMO and the COVID dummy are not significant in the pooled EGLS and in the ARDL estimation results for Model 2 ("Appendix 2"). It implies that BI's FX open market operation does not have a significant impact on the average rates of the USD interbank money market rates.

The pooled EGLS results show that SUN_OMO variable is not significant in Models 3A, 3B, and 3C ("Appendix 3"). The variable is significant in the long-run and has a positive sign in the ARDL estimation results for Model 3B. It is not significant in the short-run. Nonetheless, the impact of the SUN_OMO on the yields of medium-term SUNs is marginal because it is close to zero. The variable is not significant in the short-run and long-run ARDL estimations for Model 3A and 3C. Thus, BI's open market operations in the SUN market have no significant impacts or at most only have marginal impacts on the yields of the SUNs.

The pooled EGLS estimation results show that the interaction variable between the SUN_OMO and the COVID dummy variable is significant and has a positive sign in Model 3B. The interaction variable is significant in the short-run equation but not in the long-run equation of the ARDL estimation results. These results imply that the pandemic temporarily strengthened the impact of BI's SUN OMO on the yields of medium-term SUNs.

The TMO variable is significant in the pooled EGLS and the short-run ARDL estimation results in Model 4 ("Appendix 4"), but not significant in the long-run ARDL. Nevertheless, the impact of the TMO variable on the dependent variable is 
very close to zero. It implies that BI's total monetary operations only have marginal impacts on the sectoral indexes of Indonesia's stock market. The interaction variable between the TMO and the COVID dummy is not significant in the EGLS and in the short-run and long-run ARDL estimation results. Therefore, the pandemic does not strengthen or weaken the relationship between BI's total monetary operation and the sectoral indexes of the stock market.

\subsection{Discussion and Analysis}

The BI 7-day Reverse Repo Rate is an effective instrument in the IDR interbank money market, where the JIBORs move in the same direction with this policy rate. When BI cuts the BI 7-day Reverse Repo Rate, BI also cuts the BI deposit facility rate and BI lending facility rate. As the BI deposit facility rate falls, banks are induced to reduce their fund placement in BI, which increases IDR liquidity supply in the interbank money market and causes the JIBORs to fall. A cut in the BI lending facility rate reduces the borrowing cost from BI vis-à-vis borrowing from other banks. If a bank needs liquidity, it prefers borrowing from BI to borrowing from other banks, which reduces demand for IDR interbank money market funding and causes the JIBORs to fall.

The IDR GWM is an effective monetary instrument in the medium-term SUN market. Based on BI regulation, the IDR GWM comprises primary GWM (which is banks' IDR deposits in BI) and secondary GWM (which are in the form of the SUN instruments, BI certificates, and/or BI deposit certificates). The yields of the medium-term SUNs move in the opposite direction with the IDR GWM ratio in the short-run. When BI cut the IDR GWM ratio, banks temporarily reduce their demand for the medium-term SUN instruments because they have more liquidity to meet their short-term liabilities. The falling demand from banks causes the SUN yields to increase (or SUN prices to fall).

However, the cut in the minimum IDR GWM requirement creates an excess of liquidity for banks in the long-run. Commercial banks will increase their demand for the debt securities to place their funds, raising their debt securities holding and causing the yields of the medium-term SPN to fall (or the SUN prices to increase). Figure 13 displays the long-run positive relationship between the minimum IDR GWM ratio and total debt securities held by commercial banks. Figure 14 shows the positive long-run relationship between the GWM ratio and the yield of the medium-term SUNs.

The IDR GWM instrument also has significant short-run impacts, but not on the long-run, on Indonesia's stock market. These impacts are transmitted indirectly (i.e., through the changes in liquidity in the economy) rather directly to the stock market because commercial banks in Indonesia are not allowed to trade stocks in the stock market. The IDR GWM ratio has a negative relationship with the sectoral indexes of the stock market. A hike in the minimum IDR GWM ratio reduces the sectoral indexes of the stock market. When BI absorbs liquidity from the banking system and the overall economy, liquidity in the economy dwindles. Tighter IDR liquidity in the 


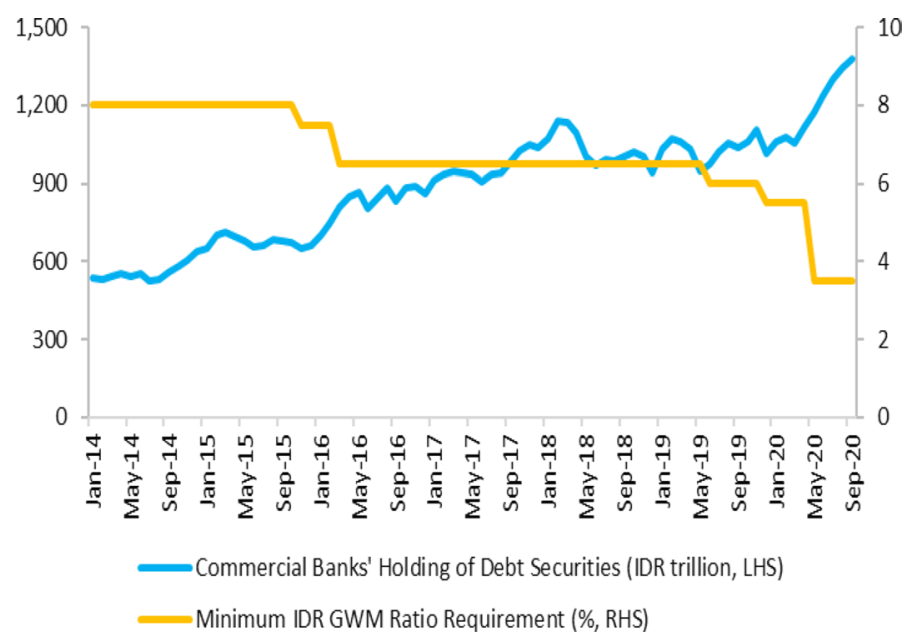

Fig. 13 The Minimum IDR GWM Ratio Requirement and Commercial Banks' Debt Securities Holding. Source: CEIC, Bloomberg

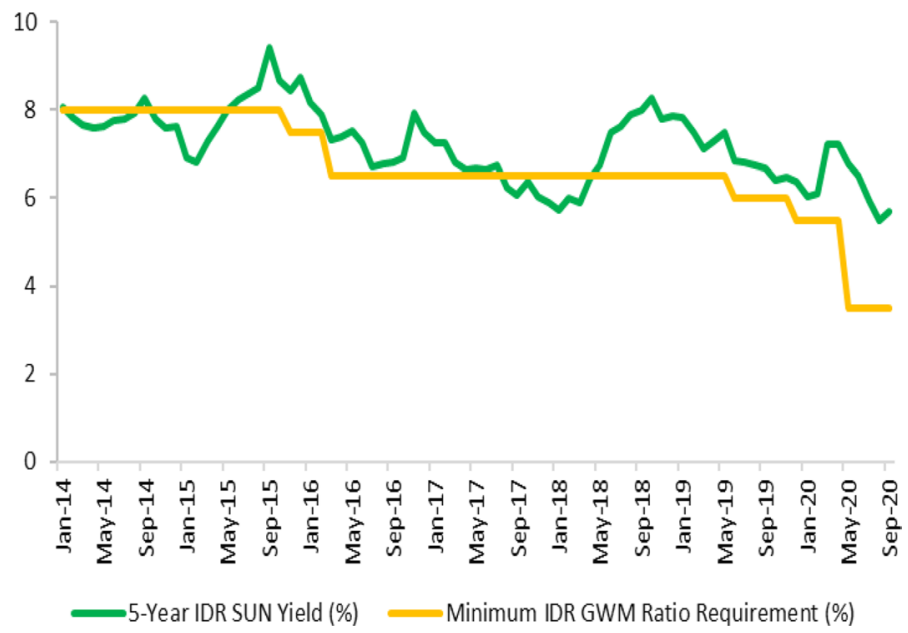

Fig. 14 The Minimum IDR GWM Ratio Requirement and the 5-Year SUN Yield. Source: Bloomberg

economy causes demand for Indonesian stocks to fall and leads to a decline in stock prices and the sectoral indexes of the stock market.

The FX GWM ratio is an effective policy instrument in the FX market. The FX_GWM variable has a negative sign in Model 5. If BI hikes (cuts) the FX GWM ratio minimum requirement, the IDR strengthens (weakens) against the USD. The result is counterintuitive if seen as causality, but sensible if seen as concurrency between the two variables. BI raised the FX GWM ratio from 1 to $8 \%$ in 2011 to absorb excess USD liquidity in the banking system when the IDR underwent an appreciating trend. BI cut the ratio from 8 to 4\% in March 2020 to 
inject USD liquidity into the banking system when the IDR was under pressure due to the COVID-19 pandemic. That said, this paper acknowledges the result as an anomaly that needs to be examined thoroughly in future studies.

BI's market operations are not effective in the IDR and USD interbank money markets, the SUN markets across tenors, and the stock market. Although the monetary operation variables are statistically significant in the IDR interbank money market (both in the short-run and long-run), the medium-term SUN market (only in the long-run), and the stock market (only in the short-run), their respective impacts on the JIBORs, the yields of the medium-term SUNs, and the sectoral indexes of the stock market are marginal. BI's monetary operation has no significant impacts on the USD interbank money market and the short-term and longterm SUN markets.

The COVID-19 pandemic strengthened the impacts of particular monetary policy instruments on the specific markets. The pandemic strengthened the policy rate on the JIBORs, both in the short-run and the long-run. The pandemic caused the IDR GWM ratio to temporarily have a greater impact on the yields of the medium and long-term SUNs compared to in the pre-pandemic period. The pandemic asserted the impact of the IDR GWM ratio on the sectoral indexes of the stock market in the short-run and the long-run.

The COVID-19 pandemic has created a temporary crisis situation in Indonesia's financial markets in March 2020, before the market started to rebound in April 2020. The policy rate and the IDR GWM as monetary policy instruments have stronger impacts in a crisis than in the non-crisis situation. Many central banks cut the policy rate and the minimum reserve ratio requirement for banks during the pandemic to inject liquidity to the market (IMF, 2020c).

From the overall estimation results, we find that there are limitations to BI's monetary policy instruments because they have significant impacts only on particular financial markets. The policy rate is effective only for the IDR and USD interbank money markets, the minimum IDR GWM ratio only for the medium-term SUN markets and the stock markets, and the minimum FX GWM ratio only for the FX market.

Moreover, the impacts of monetary instruments on the financial markets cannot be not fully transmitted to the economy. For example, BI's policy rate cuts reduce the JIBORs but with smaller magnitudes than the cuts in the policy rate. The banking credit interest rates, which use the JIBORs as the benchmarks, fall with smaller magnitudes than the JIBORs.

BI's policy rate cuts during the pandemic had reduced the JIBORs and to a smaller extent, the banking credit rates. These policy rate cuts could not prevent the banking credit from contracting in 2020 because the demand for banking credit had weakened significantly due to the pandemic. The pandemic and the PSBB have caused households' purchasing power to deteriorate and reduced the aggregate demand for goods and services. Consequently, firms curbed their production activities and their demand for banking credit. Monetary policy alone cannot resolve the demand-side problem caused by the pandemic. Fiscal stimuli are needed to restore households' purchasing power (e.g., direct cash transfers and social assistance) and business activities. 
Another example of the limitation of BI's policy instrument is the ineffectiveness of the policy rate to affect the FX market. BI often hikes the policy rate to defend the IDR from massive capital outflows. Our regression result shows that the policy rate hike is not effective for defending the IDR because other factors have more influence on the USD/IDR exchange rate. That said, the policy rate hike is needed to assure the FX market participants that $\mathrm{BI}$ is responsive to the situation while it continues intervening (i.e., selling USD) in the FX market.

Likewise, BI's open market operations are not effective in influencing the interbank money markets and the SUN markets. Nevertheless, BI's market operations are still needed to ensure the participants in the interbank money markets and the SUN markets that BI is stabilizing the markets.

In brief, BI's policy instruments are needed to maintain the stability of financial markets. Turbulent financial markets can harm the economy because the financial markets are the place where firms and the government seek funding to finance their activities in the real sector of the economy. A highly fluctuating exchange rate creates uncertainty for firms' business cash flows and the government budget related to their cross-border transactions (e.g., exports, imports, and external debts). Highly volatile interbank money market rates create uncertainty on banks' liquidity, highly volatile SUN yields create uncertainty for the government budget, and highly volatile stock prices can harm the stock market listed companies' assets.

Therefore, shock-resilience and stable financial markets are crucial for maintaining economic stability and facilitating economic growth. Consequently, BI's policies to maintain the stability of the financial markets are crucial to support the fiscal policies to recover Indonesia's economy.

\section{Conclusions}

We find that several policy instruments have significant impacts on particular financial markets both before and during the pandemic: (1) the policy rate on the IDR and USD interbank money market rates; (2) the minimum IDR GWM ratio on the medium-term SUN yields and the stock market sectoral indexes; and (3) the minimum FX GWM ratio on the FX market. BI's market operations did not have significant impact or at most are statistically significant but have marginal impacts on the IDR interbank money market, the SUN markets, and the stock market.

We also find that the COVID-19 pandemic strengthened the impacts of BI's policy instruments on the following particular markets during the pandemic than the pre-pandemic period: (a) the policy rate on the IDR interbank money market (in the short-run and long-run); (2) the minimum IDR GWM ratio on the medium-term and long-term SUN markets (only in the short-run); and (3) the minimum IDR GWM ratio on the sectoral indexes of the stock market (in the short and long-run).

We suggest BI continues to maintain the stability of financial markets to support the government efforts to restore the economy from the fiscal side. 


\section{Appendix 1}

\section{Model 1: Factors Affecting Interbank IDR Money Market Rates}

(Coefficient values in \%, t-statistics probability in brackets)

\begin{tabular}{|c|c|c|c|}
\hline \multicolumn{2}{|l|}{ Pooled EGLS model } & \multicolumn{2}{|c|}{$\begin{array}{l}\text { Panel ARDL model ARDL }(4,1,1,1,1,1,1 \text {, } \\
1,1,1)\end{array}$} \\
\hline Dependent variable & $\mathrm{D}(\mathrm{JIBOR})$ & Dependent variable & $\mathrm{D}(\mathrm{JIBOR})$ \\
\hline Regressors & & Regressors & \\
\hline Constant & $-0.0017\left(0.0005^{* * *}\right)$ & Long-run equation & \\
\hline COVID & $-0.0018(0.0407 * *)$ & COVID & $-3.2914(0.0677 *)$ \\
\hline PSBB & $-0.0035\left(0.0000^{* * *}\right)$ & PSBB & $-0.1001(0.4814)$ \\
\hline FISPACK & $0.0022\left(0.0000^{* * *}\right)$ & FISPACK & $0.1217\left(0.0469^{* *}\right)$ \\
\hline $\mathrm{D}(\mathrm{BI} 7 \mathrm{D}(-1))$ & $0.6086\left(0.0000^{* * *}\right)$ & $\mathrm{BI} 7 \mathrm{D}(-1)$ & $0.9584\left(0.0000^{* * *}\right)$ \\
\hline D(IDR_GWM) & $-0.0044(0.1063)$ & IDR_GWM & $0.1438(0.0518 *)$ \\
\hline D(MM_OMO) & $0.0000\left(0.0030^{* * *}\right)$ & MM_OMO & $0.0000\left(0.0000^{* * *}\right)$ \\
\hline D(BI7D(-1)) X COVID & $0.2665\left(0.0000^{* * *}\right)$ & BI7D $(-1)$ X COVID & $0.8121(0.0129 * *)$ \\
\hline D(IDR_GWM) X COVID & $0.0037(0.1798)$ & IDR_GWM X COVID & $-0.1583(0.1219)$ \\
\hline D(MM_OMO) X COVID & $0.0000\left(0.0115^{* *}\right)$ & MM_OMO X COVID & $0.0000(0.1013)$ \\
\hline $\operatorname{AR}(1)$ & $-0.1300(0.2922)$ & Short-run equation & \\
\hline Fixed effects (Cross) & & Constant & $-0.0568(0.3249)$ \\
\hline _ON-C & 0.00158 & ECT & $-0.1085(0.2530)$ \\
\hline$-1 \mathrm{~W}-\mathrm{C}$ & 0.00008 & $\mathrm{D}(\mathrm{JIBOR}(-1))$ & $-0.1287(0.3185)$ \\
\hline$-1 \mathrm{M}-\mathrm{C}$ & 0.00054 & $\mathrm{D}(\operatorname{JIBOR}(-2))$ & $-0.1153(0.1190)$ \\
\hline $3 \mathrm{M}-\mathrm{C}$ & -0.00060 & $\mathrm{D}(\operatorname{JIBOR}(-3))$ & $-0.0363(0.4347)$ \\
\hline$-6 \mathrm{M}-\mathrm{C}$ & -0.00077 & $\mathrm{D}(\mathrm{COVID})$ & $-1.0157\left(0.0001^{* * *}\right)$ \\
\hline \multirow[t]{8}{*}{$-1 \mathrm{Y}-\mathrm{C}$} & -0.00083 & $\mathrm{D}(\mathrm{PSBB})$ & $0.0078(0.5299)$ \\
\hline & & D(FISPACK) & $-0.0041(0.1715)$ \\
\hline & & $\mathrm{D}(\mathrm{BI} 7 \mathrm{D}(-1))$ & $0.5259(0.0000 * * *)$ \\
\hline & & D(IDR_GWM) & $-0.0007(0.9652)$ \\
\hline & & D(MM_OMO) & $0.0000(0.0050 * * *)$ \\
\hline & & $\mathrm{D}(\mathrm{BI} 7 \mathrm{D}(-1) \mathrm{X}$ COVID $)$ & $0.2147(0.0000 * * *)$ \\
\hline & & D(COVID X IDR_GWM) & $-0.0028(0.8140)$ \\
\hline & & D(COVID X MM_OMO) & $0.0000(0.8129)$ \\
\hline \multicolumn{4}{|l|}{ Weighted statistics } \\
\hline $\begin{array}{l}\text { No. of pool balanced obser- } \\
\text { vations }\end{array}$ & 5232 & No. of panel observations & $5 s 322$ \\
\hline R-squared & 0.314717 & Log likelihood & $7,007.264$ \\
\hline Adjusted R-squared & 0.312746 & & \\
\hline Prob (F-Statistics) & $0.000000^{* * *}$ & & \\
\hline DW Statistics & 2.034155 & & \\
\hline
\end{tabular}

*Significant at $\alpha=10 \%$; **significant at $\alpha=5 \%$; ***significant at $\alpha=1 \%$

Source: Author's calculation 


\section{Appendix 2}

\section{Model 2: Factors Affecting Interbank USD Money Market Rates}

(Coefficient values in \%, t-statistics probability in brackets)

\begin{tabular}{|c|c|c|c|}
\hline \multicolumn{2}{|l|}{ Pooled EGLS model } & \multicolumn{2}{|c|}{$\begin{array}{l}\text { Panel ARDL model } \\
\text { ARDL(4, 2, 2, 2, 2, 2, 2, 2, 2, 2) }\end{array}$} \\
\hline Dependent variable & $\mathrm{D}$ (USDA) & Dependent variable & $\mathrm{D}$ (USDA) \\
\hline Regressors & & Regressors & \\
\hline Constant & $0.0006\left(0.0700^{*}\right)$ & Long-run Equation & \\
\hline COVID & $-0.0043(0.0142 * *)$ & COVID & $-0.5548(0.6952)$ \\
\hline PSBB & $0.0013(0.4069)$ & PSBB & $0.2776\left(0.0269^{* *}\right)$ \\
\hline FISPACK & $0.0000(0.9854)$ & FISPACK & $-0.1704(0.0947 *)$ \\
\hline $\mathrm{D}(\mathrm{ER}(-1))$ & $0.0000(0.0303 * *)$ & $\mathrm{ER}(-1)$ & $0.0002(0.0000 * * *)$ \\
\hline $\mathrm{D}(\mathrm{BI} 7 \mathrm{D}(-1))$ & $0.0374(0.0090 * * *)$ & $\operatorname{BI7D}(-1)$ & $0.1917(0.0000 * * *)$ \\
\hline D(FX_GWM) & $0.0058(0.1124)$ & FX_GWM & $-0.0275(0.6506)$ \\
\hline D(FX_MM_OMO) & $0.0000(0.3153)$ & FX_MM_OMO & $0.0000(0.9363)$ \\
\hline $\mathrm{D}(\mathrm{BI} 7 \mathrm{D}(-1)) \mathrm{X}$ COVID & $-0.0592\left(0.0736^{*}\right)$ & BI7D(-1) X COVID & $0.1229(0.6656)$ \\
\hline $\begin{array}{l}\text { D(FX_MM_OMO) X } \\
\text { COVID }\end{array}$ & $0.0000(0.7409)$ & FX_MM_OMO X COVID & $0.0000(0.3480)$ \\
\hline $\operatorname{AR}(1)$ & $-0.5919\left(0.0000^{* * *}\right)$ & Short-run equation & \\
\hline $\mathrm{AR}(2)$ & $-0.3208\left(0.0000^{* * *}\right)$ & & \\
\hline Fixed effects (Cross) & & Constant & $-0.0814\left(0.0000^{* * *}\right)$ \\
\hline$-1 \mathrm{M}-\mathrm{C}$ & -0.00003 & $\mathrm{ECT}$ & $-0.0417\left(0.0000^{* * *}\right)$ \\
\hline$-3 \mathrm{M}-\mathrm{C}$ & 0.00001 & $\mathrm{D}(\operatorname{USDA}(-1))$ & $-0.6244(0.0000 * * *)$ \\
\hline _6M-C & 0.00000 & $\mathrm{D}(\operatorname{USDA}(-2))$ & $-0.4222\left(0.0000^{* * *}\right)$ \\
\hline
\end{tabular}


Pooled EGLS model

\begin{tabular}{|c|c|c|c|}
\hline & & $\operatorname{ARDL}(4,2,2,2,2,2,2,2$ & \\
\hline Dependent variable & $\mathrm{D}$ (USDA) & Dependent variable & $\mathrm{D}(\mathrm{USDA})$ \\
\hline $1 \mathrm{Y}-\mathrm{C}$ & 0.00002 & $\mathrm{D}(\mathrm{USDA}(-3))$ & $-0.1936(0.0000 * * *)$ \\
\hline & & D(COVID) & $0.0860(0.3922)$ \\
\hline & & $\mathrm{D}(\mathrm{COVID}(-1))$ & $0.5478(0.1487)$ \\
\hline & & $\mathrm{D}(\mathrm{PSBB})$ & $0.0003(0.9705)$ \\
\hline & & $\mathrm{D}(\operatorname{PSBB}(-1))$ & $-0.0010(0.7938)$ \\
\hline & & D(FISPACK) & $-0.0003(0.9299)$ \\
\hline & & $\mathrm{D}(\mathrm{FISPACK}(-1))$ & $0.0107\left(0.0033^{* * *}\right)$ \\
\hline & & $\mathrm{D}(\mathrm{ER}(-1))$ & $0.0000(0.1535)$ \\
\hline & & $\mathrm{D}(\mathrm{ER}(-2))$ & $0.0000(0.8919)$ \\
\hline & & $\mathrm{D}(\mathrm{BI} 7 \mathrm{D}(-1))$ & $0.0000(0.9992)$ \\
\hline & & $\mathrm{D}(\mathrm{BI} 7 \mathrm{D}(-2))$ & $0.0846(0.2059)$ \\
\hline & & D(FX_GWM) & $0.0091(0.0000 * * *)$ \\
\hline & & D(FX_GWM (-1)) & $-0.0046\left(0.0231^{* *}\right)$ \\
\hline & & D(FX_MM_OMO) & $0.0000(0.2260)$ \\
\hline & & D(FX_MM_OMO(-1)) & $0.0000(0.5398)$ \\
\hline & & $\mathrm{D}(\mathrm{BI} 7 \mathrm{D}(-1) \mathrm{X}$ COVID $)$ & $-0.0212(0.2387)$ \\
\hline & & $\begin{array}{l}\mathrm{D}(\mathrm{BI} 7 \mathrm{D}(-2) \times \text { COVID } \\
\quad(-1))\end{array}$ & $-0.1021(0.1240)$ \\
\hline & & $\begin{array}{l}\text { D(COVID) X FX_MM_ } \\
\text { OMO) }\end{array}$ & $0.0000(0.3084)$ \\
\hline & & $\begin{array}{l}\text { D(COVID }(-1) \text { X FX_ } \\
\text { MM_OMO }(-1))\end{array}$ & $0.0000(0.6884)$ \\
\hline Weighted statistics & & & \\
\hline $\begin{array}{l}\text { No. of pool balanced obser- } \\
\text { vations }\end{array}$ & 3896 & No. of panel observations & 3896 \\
\hline R-squared & 0.284773 & Log likelihood & $7,888.045$ \\
\hline Adjusted R-squared & 0.282193 & & \\
\hline Prob (F-Statistics) & $0.000000 * * *$ & & \\
\hline DW Statistics & 2.130795 & & \\
\hline
\end{tabular}

*Significant at $\alpha=10 \%$; **significant at $\alpha=5 \%$; ***significant at $\alpha=1 \%$

The interaction variable between the FX GWM and the COVID-19 dummy is discarded from Model 2 because it causes a multicollinearity problem

Source: Author's calculation

\section{Appendix 3}

\section{Model 3A: Factors Affecting Short-term Government Bond Yields}

(Coefficient values in \%, t-statistics probability in brackets) 
Pooled EGLS model

\begin{tabular}{|c|c|c|c|}
\hline & & $1,1,1,1,1,1)$ & \\
\hline Dependent variable & $\mathrm{D}(\mathrm{STGB})$ & Dependent variable & $\mathrm{D}(\mathrm{STGB})$ \\
\hline Regressors & & Regressors & \\
\hline Constant & $-0.0031(0.3178)$ & Long-run equation & \\
\hline COVID & $-0.0244(0.0290 * *)$ & COVID & $1.7335(0.7568)$ \\
\hline D(US_GB_3M(-1)) & $0.0692(0.2161)$ & US_GB_3M(-1) & $0.0326(0.9218)$ \\
\hline $\mathrm{D}(\mathrm{ER})$ & $0.0000(0.4416)$ & ER & $0.0000(0.8932)$ \\
\hline $\mathrm{D}(\mathrm{JCI})$ & $0.0000(0.5512)$ & JCI & $-0.0003(0.4183)$ \\
\hline PSBB & $0.0007(0.9508)$ & PSBB & $0.6737\left(0.0819^{*}\right)$ \\
\hline FISPACK & $0.0087(0.1762)$ & FISPACK & $-0.2882(0.2285)$ \\
\hline $\mathrm{D}(\mathrm{BI} 7 \mathrm{D}(-1))$ & $0.0632(0.4759)$ & $\operatorname{BI7D}(-1)$ & $0.4013(0.0174 * *)$ \\
\hline D(IDR_GWM) & $-0.1252(0.1046)$ & IDR_GWM & $0.0223(0.9310)$ \\
\hline D(SUN_OMO) & $0.0000(0.4446)$ & SUN_OMO & $0.0000\left(0.0579^{*}\right)$ \\
\hline $\mathrm{D}(\mathrm{BI} 7 \mathrm{D}(-1)) \mathrm{X}$ COVID & $0.1408(0.3194)$ & BI7D(-1) X COVID & $-0.7743(0.4477)$ \\
\hline D(IDR_GWM) X COVID & $0.1248(0.1269)$ & IDR_GWM X COVID & $0.0148(0.9618)$ \\
\hline D(SUN_OMO) X COVID & $0.0000(0.2037)$ & SUN_OMO X COVID & $0.0000(0.3764)$ \\
\hline Fixed Effects (Cross) & & Short-run equation & \\
\hline$-3 \mathrm{M}-\mathrm{C}$ & 0.00030 & Constant & $0.2019(0.0765 *)$ \\
\hline $6 \mathrm{M}-\mathrm{C}$ & -0.00030 & ECT & $-0.0469(0.0842 *)$ \\
\hline & & $\mathrm{D}(\mathrm{COVID})$ & $-1.2033\left(0.0326^{* *}\right)$ \\
\hline & & D(US_GB_3M(-1)) & $0.0964(0.3499)$ \\
\hline & & $\mathrm{D}(\mathrm{ER})$ & $0.0000(0.5293)$ \\
\hline & & $\mathrm{D}(\mathrm{JCI})$ & $0.0000(0.4205)$ \\
\hline & & $\mathrm{D}(\mathrm{PSBB})$ & $0.0025(0.3705)$ \\
\hline & & D(FISPACK) & $0.0399\left(0.0035^{* *}\right)$ \\
\hline & & $\mathrm{D}(\mathrm{BI} 7 \mathrm{D}(-1))$ & $0.1233\left(0.0000^{* * *}\right)$ \\
\hline & & D(IDR_GWM) & $-0.1523(0.2807)$ \\
\hline & & D(SUN_OMO) & $0.0000(0.3108)$ \\
\hline & & D(BI7D(-1) X COVID) & $0.0999(0.0529 *)$ \\
\hline & & D(IDR_GWM X COVID) & $0.1579(0.2650)$ \\
\hline & & D(SUN_OMO X COVID) & $0.0000\left(0.0000^{* * *}\right)$ \\
\hline Weighted statistics & & & \\
\hline $\begin{array}{l}\text { No. of pool balanced observa- } \\
\text { tions }\end{array}$ & 958 & No. of panel observations & $\begin{array}{l}1099 \\
1.199 .393\end{array}$ \\
\hline R-squared & 0.021801 & Log likelihood & \\
\hline Adjusted R-squared & 0.008330 & & \\
\hline Prob (F-Statistics) & $0.091011^{*}$ & & \\
\hline DW Statistics & 2.107103 & & \\
\hline
\end{tabular}

*Significant at $\alpha=10 \%$; **significant at $\alpha=5 \%$; ***significant at $\alpha=1 \%$

Source: Author's calculation 


\section{Model 3B: Factors Affecting Medium-term Government Bond Yields}

(Coefficient values in \%, t-statistics probability in brackets).

\begin{tabular}{|c|c|c|c|}
\hline \multicolumn{2}{|l|}{ Pooled EGLS model } & \multicolumn{2}{|c|}{$\begin{array}{l}\text { Panel ARDL model } \\
\text { ARDL(3,1,1,1,1,1,1,1,1,1,1,1,1) }\end{array}$} \\
\hline Dependent variable & D(MTGB) & Dependent variable & $\mathrm{D}(\mathrm{MTGB})$ \\
\hline Regressors & & Regressors & \\
\hline Constant & $-0.0020(0.0398 * *)$ & Long-run Equation & \\
\hline COVID & $-0.0174(0.0017 * * *)$ & COVID & $-8.1103\left(0.0546^{*}\right)$ \\
\hline D(US_GB_5Y(-1)) & $0.0689(0.0026 * * *)$ & US_GB_5Y(-1) & $0.4712(0.0014 * * *)$ \\
\hline $\mathrm{D}(\mathrm{ER})$ & $0.0004(0.0000 * * *)$ & ER & $0.0006(0.0002 * * *)$ \\
\hline PSBB & $-0.0314(0.0000 * * *)$ & PSBB & $-0.1859(0.6014)$ \\
\hline FISPACK & $0.0156(0.0001 * * *)$ & FISPACK & $0.4194\left(0.0136^{* *}\right)$ \\
\hline $\mathrm{D}(\mathrm{JCI})$ & $-0.0002(0.0000 * * *)$ & JCI & $-0.0011(0.0000 * * *)$ \\
\hline $\mathrm{D}(\mathrm{BI} 7 \mathrm{D}(-1))$ & $0.0112(0.6255)$ & $\mathrm{BI} 7 \mathrm{D}(-1)$ & $0.3040\left(0.0042^{* * *}\right)$ \\
\hline $\mathrm{D}(\mathrm{GWM})$ & $-0.0656\left(0.0010^{* * *}\right)$ & IDR_GWM & $0.4421\left(0.0440^{* *}\right)$ \\
\hline D(SUN_OMO) & $0.0000(0.1412)$ & SUN_OMO & $0.0000(0.0000 * * *)$ \\
\hline $\mathrm{D}(\mathrm{BI} 7 \mathrm{D}(-1))$ X COVID & $-0.0201(0.7138)$ & BI7D $(-1)$ X COVID & $1.6901(0.0414 * *)$ \\
\hline D(IDR_GWM) X COVID & $0.0691(0.0006 * * *)$ & IDR_GWM X COVID & $-0.3020(0.3056)$ \\
\hline D(SUN_OMO) X COVID & $0.0000\left(0.0008^{* * *}\right)$ & SUN_OMO X COVID & $0.0000\left(0.0538^{*}\right)$ \\
\hline $\operatorname{AR}(1)$ & $0.11736\left(0.0000^{* * *}\right)$ & Short-run equation & \\
\hline Fixed effects (Cross) & & Constant & $0.0041(0.4364)$ \\
\hline$-1 \mathrm{Y}-\mathrm{C}$ & -0.00109 & ECT & $-0.0240(0.0000 * * *)$ \\
\hline$-2 \mathrm{Y}-\mathrm{C}$ & -0.00100 & D(ID_GB(-1)) & $0.1289(0.0036 * * *)$ \\
\hline$-3 \mathrm{Y}-\mathrm{C}$ & 0.00031 & D(ID_GB(-2)) & $-0.0240(0.2491)$ \\
\hline$-5 \mathrm{Y}-\mathrm{C}$ & 0.00034 & $\mathrm{D}(\mathrm{COVID})$ & $-0.6849(0.0179 * *)$ \\
\hline \multirow[t]{11}{*}{$-7 \mathrm{Y}-\mathrm{C}$} & 0.00144 & D(US_GB_5Y(-1)) & $0.0700(0.0014 * * *)$ \\
\hline & & $\mathrm{D}(\mathrm{ER})$ & $0.0003(0.0000 * * *)$ \\
\hline & & $\mathrm{D}(\mathrm{PSBB})$ & $0.0080(0.5008)$ \\
\hline & & D(FISPACK) & $0.0819(0.0001 * * *)$ \\
\hline & & $\mathrm{D}(\mathrm{JCI})$ & $-0.0002(0.0000 * * *)$ \\
\hline & & $\mathrm{D}(\mathrm{BI} 7 \mathrm{D}(-1))$ & $0.0007(0.9558)$ \\
\hline & & D(IDR_GWM) & $-0.0926\left(0.0000^{* * *}\right)$ \\
\hline & & D(SUN_OMO) & $0.0000(0.8342)$ \\
\hline & & D(BI7D(-1) X COVID) & $0.0339(0.5380)$ \\
\hline & & D(IDR_GWM X COVID) & $0.0763(0.0000 * * *)$ \\
\hline & & D(SUN_OMO X COVID) & $0.0000(0.0084 * * *)$ \\
\hline \multicolumn{4}{|l|}{ Weighted statistics } \\
\hline $\begin{array}{l}\text { No. of pool balanced obser- } \\
\text { vations }\end{array}$ & 4350 & No. of Panel Observations & 4425 \\
\hline
\end{tabular}




\begin{tabular}{|c|c|c|c|}
\hline \multicolumn{2}{|l|}{ Pooled EGLS model } & \multicolumn{2}{|c|}{$\begin{array}{l}\text { Panel ARDL model } \\
\operatorname{ARDL}(3,1,1,1,1,1,1,1,1,1,1,1,1)\end{array}$} \\
\hline Dependent variable & D(MTGB) & Dependent variable & D(MTGB) \\
\hline R-squared & 0.268820 & Log likelihood & $6,782.464$ \\
\hline Adjusted R-squared & 0.265951 & & \\
\hline Prob (F-Statistics) & $0.000000 * * *$ & & \\
\hline DW Statistics & 1.998102 & & \\
\hline
\end{tabular}

*Significant at $\alpha=10 \%$; **significant at $\alpha=5 \%$; *** significant at $\alpha=1 \%$

Source: Author's calculation

\section{Model 3C: Factors Affecting Long-term Government Bond Yields}

(Coefficient values in \%, t-statistics probability in brackets)

\begin{tabular}{|c|c|c|c|}
\hline \multicolumn{2}{|l|}{ Pooled EGLS model } & \multicolumn{2}{|c|}{$\begin{array}{l}\text { Panel ARDL model } \\
\text { ARDL(3,1,1,1,1,1,1,1,1,1,1,1,1) }\end{array}$} \\
\hline Dependent variable & $\mathrm{D}$ (LTGB) & Dependent variable & $\mathrm{D}$ (LTGB) \\
\hline Regressors & & Regressor & \\
\hline Constant & $-0.0010(0.3590)$ & Long-run Equation & \\
\hline COVID & $-0.0066(0.2410)$ & COVID & $-3.1835(0.1340)$ \\
\hline D(US_GB_10Y(-1)) & $0.1259(0.0000 * * *)$ & US_GB_10Y(-1) & $0.3930\left(0.0000^{* * *}\right)$ \\
\hline $\mathrm{D}(\mathrm{ER})$ & $0.0004(0.0000 * * *)$ & ER & $0.0004(0.0000 * * *)$ \\
\hline PSBB & $-0.0127(0.0339 * *)$ & PSBB & $0.1762(0.3087)$ \\
\hline FISPACK & $0.0064(0.0643 *)$ & FISPACK & $0.1088(0.1895)$ \\
\hline $\mathrm{D}(\mathrm{JCI})$ & $-0.0002\left(0.0000^{* * *}\right)$ & JCI & $-0.0007(0.0000 * * *)$ \\
\hline $\mathrm{D}(\mathrm{BI} 7 \mathrm{D}(-1))$ & $-0.0076(0.7677)$ & $\operatorname{BI} 7 \mathrm{D}(-1)$ & $0.5320\left(0.0000^{* * *}\right)$ \\
\hline D(IDR_GWM) & $-0.0578\left(0.0896^{*}\right)$ & IDR_GWM & $0.0505(0.6596)$ \\
\hline D(SUN_OMO) & $0.0000(0.5910)$ & SUN_OMO & $0.0000(0.3710)$ \\
\hline $\mathrm{D}(\mathrm{BI} 7 \mathrm{D}(-1)) \mathrm{X}$ COVID & $0.0395(0.4724)$ & BI7D(-1) X COVID & $0.5427(0.1819)$ \\
\hline D(IDR_GWM) X COVID & $0.0648\left(0.0727^{*}\right)$ & IDR_GWM X COVID & $0.0368(0.8079)$ \\
\hline D(SUN_OMO) X COVID & $0.0000(0.0844 *)$ & SUN_OMO X COVID & $0.0000(0.6332)$ \\
\hline $\operatorname{AR}(1)$ & $0.1488(0.0000 * * *)$ & Short-run equation & \\
\hline Fixed effects (Cross) & & Constant & $0.1256(0.0000 * * *)$ \\
\hline$-10 \mathrm{Y}-\mathrm{C}$ & -0.00012 & ECT & $-0.0464(0.0000 * * *)$ \\
\hline$-15 \mathrm{Y}-\mathrm{C}$ & 0.00019 & D(ID_GB(-1)) & $0.1712(0.0077 * * *)$ \\
\hline _20Y-C & 0.00054 & D(ID_GB(-2)) & $-0.0967(0.0000 * * *)$ \\
\hline
\end{tabular}




\begin{tabular}{|c|c|c|c|}
\hline \multicolumn{2}{|l|}{ Pooled EGLS model } & \multicolumn{2}{|c|}{$\begin{array}{l}\text { Panel ARDL model } \\
\text { ARDL }(3,1,1,1,1,1,1,1,1,1,1,1,1)\end{array}$} \\
\hline \multirow[b]{2}{*}{ Dependent variable } & \multirow[b]{2}{*}{ D(LTGB) } & & \\
\hline & & Dependent variable & D(LTGB) \\
\hline \multirow[t]{12}{*}{$-30 \mathrm{Y}-\mathrm{C}$} & \multirow[t]{12}{*}{-0.00062} & $\mathrm{D}(\mathrm{COVID})$ & $-1.2326(0.0025 * * *)$ \\
\hline & & D(US_GB_10Y(-1)) & $0.1197(0.0109 * *)$ \\
\hline & & $\mathrm{D}(\mathrm{ER})$ & $0.0004\left(0.0000^{* * *}\right)$ \\
\hline & & $\mathrm{D}(\mathrm{PSBB})$ & $0.0246(0.0824 *)$ \\
\hline & & D(FISPACK) & $0.0027(0.8184)$ \\
\hline & & $\mathrm{D}(\mathrm{JCI})$ & $-0.0002(0.0232 * *)$ \\
\hline & & $\mathrm{D}(\mathrm{BI} 7 \mathrm{D}(-1))$ & $-0.0193(0.4662)$ \\
\hline & & D(IDR_GWM) & $-0.0881(0.0000 * * *)$ \\
\hline & & D(SUN_OMO) & $0.0000(0.2015)$ \\
\hline & & $\mathrm{D}\left(\mathrm{BI} 7 \mathrm{D}(-1)^{*} \mathrm{COVID}\right)$ & $0.1474\left(0.0178^{* *}\right)$ \\
\hline & & D(IDR_GWM X COVID) & $0.0744(0.0004 * * *)$ \\
\hline & & D(SUN_OMO X COVID) & $0.0000(0.0000 * * *)$ \\
\hline \multicolumn{4}{|l|}{ Weighted statistics } \\
\hline $\begin{array}{l}\text { No. of pool balanced obser- } \\
\text { vations }\end{array}$ & 3480 & No. of panel observations & 3540 \\
\hline R-squared & 0.327930 & Log likelihood & $5,938.535$ \\
\hline Adjusted R-squared & 0.324825 & & \\
\hline Prob (F-Statistics) & $0.000000 * * *$ & & \\
\hline DW Statistics & 1.974335 & & \\
\hline
\end{tabular}

*significant at $\alpha=10 \%$; **significant at $\alpha=5 \%$; ***significant at $\alpha=1 \%$

Source: Author's calculation

\section{Appendix 4}

\section{Model 4: Factors Affecting Sectoral Indexes of Indonesia Stock Exchange}

(Coefficient values in \%, t-statistics probability in brackets)

\begin{tabular}{|c|c|c|c|}
\hline \multicolumn{2}{|l|}{ Pooled EGLS model } & \multicolumn{2}{|c|}{$\begin{array}{l}\text { Panel ARDL model } \\
\text { ARDL(4, 1, 1, 1, 1, 1, 1, 1, 1, 1, 1, 1, 1, 1, 1, 1) }\end{array}$} \\
\hline Dependent variable & $\mathrm{D}(\mathrm{JAK})$ & Dependent variable & $\mathrm{D}(\mathrm{JAK})$ \\
\hline Regressors & & Regressors & \\
\hline Constant & $-0.1487(0.1613)$ & Long-run equation & \\
\hline COVID & $-2.8804\left(0.0000^{* * *}\right)$ & COVID & $-1,974.5(0.7046)$ \\
\hline $\mathrm{D}(\operatorname{VIX}(-1))$ & $0.0223(0.8743)$ & $\operatorname{VIX}(-1)$ & $-12.9(0.1616)$ \\
\hline D(US_SPX $(-1))$ & $0.0099(0.2485)$ & US_SPX(-1) & $-0.6(0.1349)$ \\
\hline D(SG_STI) & $0.0694(0.0000 * * *)$ & SG_STI & $-0.7(0.1119)$ \\
\hline D(CN_SHCOMP) & $0.0149\left(0.0000^{* * *}\right)$ & CN_SHCOMP & $-0.5(0.1156)$ \\
\hline $\mathrm{D}(\mathrm{ER})$ & $-0.0147\left(0.0000^{* * *}\right)$ & ER & $0.6(0.0157 * *)$ \\
\hline
\end{tabular}




\begin{tabular}{|c|c|c|c|}
\hline \multicolumn{2}{|l|}{ Pooled EGLS model } & \multicolumn{2}{|c|}{$\begin{array}{l}\text { Panel ARDL model } \\
\text { ARDL(4, 1, 1, 1, 1, 1, 1, 1, 1, 1, 1, 1, 1, 1, 1, 1) }\end{array}$} \\
\hline Dependent variable & $\mathrm{D}(\mathrm{JAK})$ & Dependent variable & $\mathrm{D}(\mathrm{JAK})$ \\
\hline$\overline{\mathrm{D}\left(\mathrm{ID} \_G B \_10 \mathrm{Y}\right)}$ & $-33.9498(0.0000 * * *)$ & ID_GB_10Y & $-686.5(0.0028 * * *)$ \\
\hline PSBB & $0.9018(0.3645)$ & PSBB & $936.7(0.0221 * *)$ \\
\hline FISPACK & $0.3753(0.4655)$ & FISPACK & $-158.8(0.3522)$ \\
\hline $\mathrm{D}(\mathrm{BI} 7 \mathrm{D}(-1))$ & $1.9001(0.5214)$ & $\mathrm{BI7D}(-1)$ & $86.6(0.4392)$ \\
\hline D(IDR_GWM) & $-17.4492(0.0008 * * *)$ & IDR_GWM & $432.7(0.0924 *)$ \\
\hline $\mathrm{D}(\mathrm{TMO})$ & $0.0000(0.0001 * * *)$ & TMO & $0.0(0.9439)$ \\
\hline $\mathrm{D}(\mathrm{BI} 7 \mathrm{D}(-1)) \times$ COVID & $-9.3569(0.2047)$ & BI7D $(-1)$ X COVID & $1,249.6(0.1994)$ \\
\hline D(IDR_GWM) X COVID & $16.9175\left(0.0011^{* * *}\right)$ & IDR_GWM X COVID & $-778.9\left(0.0114^{* *}\right)$ \\
\hline $\mathrm{D}(\mathrm{TMO}) *$ COVID & $0.0000(0.9951)$ & TMO X COVID & $0.0(0.2240)$ \\
\hline Fixed effects (Cross) & & Short-run equation & \\
\hline _AGRI-C & -0.64813 & Constant & $5.3496(0.0149 * *)$ \\
\hline _BIND-C & 0.44154 & ECT & $-0.0049\left(0.0000^{* * *}\right)$ \\
\hline CONS-C & -0.48014 & $\mathrm{D}(\mathrm{JAK}(-1))$ & $0.0068(0.6701)$ \\
\hline FIN-C & 0.55505 & $\mathrm{D}(\mathrm{JAK}(-2))$ & $-0.0713\left(0.0000^{* * *}\right)$ \\
\hline _INFR-C & 0.12145 & $\mathrm{D}(\mathrm{JAK}(-3))$ & $-0.0101(0.5787)$ \\
\hline MIND-C & -0.23156 & $\mathrm{D}(\mathrm{COVID})$ & $-58.8674(0.3095)$ \\
\hline _MINE-C & -0.09875 & $\mathrm{D}(\mathrm{VIX}(-1))$ & $0.2661(0.1392)$ \\
\hline _PROP-C & 0.20204 & D(US_SPX(-1)) & $0.0243(0.0196 * *)$ \\
\hline \multirow[t]{12}{*}{$-T R A D-C$} & 0.13848 & $\mathrm{D}\left(\mathrm{SG} \_\mathrm{STI}\right)$ & $0.1023(0.0000 * * *)$ \\
\hline & & D(CN_SHCOMP) & $0.0260(0.0000 * * *)$ \\
\hline & & $\mathrm{D}(\mathrm{ER})$ & $-0.0268(0.0000 * * *)$ \\
\hline & & D(ID_GB_10Y) & $-46.5219(0.0000 * * *)$ \\
\hline & & $\mathrm{D}(\mathrm{PSBB})$ & $-1.1545(0.5553)$ \\
\hline & & D(FISPACK) & $3.6550\left(0.0446^{* *}\right)$ \\
\hline & & $\mathrm{D}(\mathrm{BI} 7 \mathrm{D}(-1))$ & $-1.5628(0.7480)$ \\
\hline & & D(IDR_GWM) & $-28.3005\left(0.0000^{* * *}\right)$ \\
\hline & & $\mathrm{D}(\mathrm{TMO})$ & $-0.0001(0.0000 * * *)$ \\
\hline & & $\mathrm{D}(\mathrm{BI} 7 \mathrm{D}(-1) \mathrm{X}$ COVID) & $-20.9169(0.1188)$ \\
\hline & & D(IDR_GWM X COVID) & $27.6687\left(0.0000^{* * *}\right)$ \\
\hline & & D(TMO X COVID) & $0.0000(0.5448)$ \\
\hline \multicolumn{4}{|l|}{ Weighted statistics } \\
\hline \multirow{2}{*}{$\begin{array}{l}\text { No. of pool balanced } \\
\text { observations }\end{array}$} & 7929 & No. of panel observations & 7929 \\
\hline & & Log likelihood & $-3,0525.73$ \\
\hline R-squared & 0.167009 & & \\
\hline Adjusted R-squared & 0.164585 & & \\
\hline Prob (F-Statistics) & $0.000000 * * *$ & & \\
\hline DW Statistics & 1.989424 & & \\
\hline
\end{tabular}

*Significant at $\alpha=10 \%$; **significant at $\alpha=5 \%$; ***significant at $\alpha=1 \%$

Source: Author's calculation 


\section{Appendix 5}

\section{Model 5: Factors Affecting USD/IDR Exchange Rate}

(Coefficient values in \%, t-statistics probability in brackets)

\begin{tabular}{|c|c|c|c|}
\hline \multicolumn{2}{|l|}{ OLS model } & \multicolumn{2}{|l|}{ ECM model } \\
\hline Dependent variable & $\mathrm{D}(\mathrm{ER})$ & Dependent variable & $\mathrm{D}(\mathrm{ER})$ \\
\hline \multicolumn{2}{|l|}{ Regressors } & \multicolumn{2}{|l|}{ Regressors } \\
\hline Constant & $-0.7932(0.7311)$ & Constant & $-0.4933(0.8233)$ \\
\hline COVID & $31.4507(0.0029 * * *)$ & $\mathrm{ECT}(-4)$ & $-0.0303(0.0429 * *)$ \\
\hline D(DXY) & $27.2329(0.0000 * * *)$ & COVID $(-4)$ & $65.4872\left(0.0015^{* * *}\right)$ \\
\hline D(ID_USDA_1M) & $-30.9572(0.5374)$ & $\mathrm{D}(\mathrm{DXY}(-4))$ & $24.1015(0.1164)$ \\
\hline D(ID_GB_3M) & $-18.3319(0.4755)$ & D(ID_USDA_1M(-4) & $-68.3634(0.2426)$ \\
\hline D(ID_GB_5Y) & $319.5011\left(0.0000^{* * *}\right)$ & D(ID_GB_3M(-4)) & $43.7479(0.1970)$ \\
\hline D(ID_GB_10Y) & $237.0181(0.0001 * * *)$ & D(ID_GB_5Y(-4)) & $273.4094(0.2367)$ \\
\hline $\mathrm{D}(\mathrm{JCI})$ & $-0.1569\left(0.0000^{* * *}\right)$ & D(ID_GB_10Y(-4)) & $-195.4811(0.3085)$ \\
\hline PSBB & $20.6995(0.0023 * * *)$ & $\mathrm{D}(\mathrm{JCI}(-4))$ & $0.0064(0.9384)$ \\
\hline FISPACK & $-20.6510\left(0.0001^{* * *}\right)$ & $\operatorname{PSBB}(-4)$ & $20.6542(0.2248)$ \\
\hline $\mathrm{D}(\mathrm{BI} 7 \mathrm{D})$ & $-11.1656(0.8463)$ & FISPACK $(-4)$ & $-32.2473\left(0.0056^{* * *}\right)$ \\
\hline D(FX_GWM) & $-34.5097\left(0.0096^{* * *}\right)$ & $\mathrm{D}(\mathrm{BI} 7 \mathrm{D}(-4))$ & $40.1931(0.3230)$ \\
\hline \multirow[t]{2}{*}{ D(BI7D) X COVID } & $-417.3297\left(0.0006^{* * *}\right)$ & D(FX_GWM(-4)) & $-20.2300(0.0182 * *)$ \\
\hline & & $\mathrm{D}(\mathrm{BI} 7 \mathrm{D}(-4)) \times \mathrm{COVID}(-4)$ & $212.4921(0.0419 * *)$ \\
\hline No. of observations & 680 & No. of observations & 673 \\
\hline \multirow[t]{3}{*}{ R-squared } & 0.485259 & R-squared & 0.077408 \\
\hline & & Adjusted R-squared & 0.059208 \\
\hline & & Prob (F-Statistics) & $0.000000^{* * *}$ \\
\hline Adjusted R-squared & 0.475999 & DW Statistics & 1.822228 \\
\hline Prob (F-Statistics) & $0.000000^{* * *}$ & & \\
\hline DW Statistics & 1.911947 & & \\
\hline
\end{tabular}

*Significant at $\alpha=10 \%$; **significant at $\alpha=5 \%$; ***sgnificant at $\alpha=1 \%$

Source: Author's calculation

\section{References}

Acemoglu, D., Chernozhukov, V., Werning, I., and Whinston, M.D. (2020). A Multi-Risk SIR model with optimally targeted lockdown. NBER Working Paper Series, No. 27102. National Bureau of Economic Research.

Aldasoro, I., Fender, I., Hardy, B., and Tarashev, N. (2020). Effects of COVID-19 on the banking sector: the market's assessment. BIS Bulletin, p. 12. Bank for International Settlements

Asteriou, D., Pilbeam, K., \& EnyPratiwi, C. E. (2021). Public debt and economic growth: Panel data evidence for Asian countries. Journal of Economics and Finance, 45, 270-287.

Ari, A., Chen, S., and Ratnovski, L. (2020). COVID-19 and non-performing loans: Lessons from past crises. ECB Research Bulletin, p. 71. European Central Bank. https://ssrn.com/abstract=3632272 
Asian Development Bank. (2020). An updated assessment of the economic impact of COVID-19. ADB Briefs, p. 133. Manila: Asian Development Bank.

Barro, R. J., Ursúa, J.F., and Weng, J. (2020). The Coronavirus and the great influenza pandemic: Lessons from the "Spanish Flu" for the coronavirus's potential effects on mortality and economic activity. NBER Working Paper Series No. 26866. National Bureau of Economic Research.

Beirne, J., Renzhi N., Sugandi, E., Volz U. (2020). Financial market and capital flow dynamics during the COVID-19 pandemic. ADBI Working Paper Series, p. 1158. Asian Development Bank Institute.

Beirne, J., Renzhi N., Sugandi E., Volz U. (2021a). COVID-19, asset markets and capital flows. Pacific Economic Review, Special Issue Article. Wiley Journals. https://doi.org/10.1111/1468-0106.12368

Beirne, J., Renzhi, N., \& Volz, U. (2021). Local currency bond markets, foreign investor participation and capital flow volatility in emerging Asia. Singapore Economic Review. https://doi.org/10.1142/S0217 590821410083

Boissay, F., Rees, D., and Rungcharoenkitkul, P. (2020). Dealing with COVID-19: Understanding the policy choices. BIS Bulletin, p. 19. Bank for International Settlements.

Cheung, Y.-W., Chinn, M. D., \& Fujii, E. (2010). China's current account and exchange rate. In S. J. Wei (Ed.), China's growing role in world trade (Vol. 7, pp. 231-271). University of Chicago Press.

Correia, S., Luck, S., and Verner, E. (2020). Pandemics depress the economy, public health interventions do not: Evidence from the $1918 \mathrm{Flu}$. https://ssrn.com/abstract=3561560

Christopoulos, D. K., \& Tsionas, E. G. (2004). Financial development and economic growth: Evidence from panel unit root and cointegration tests. Journal of Development Economics, 73(1), 55-74.

Esteves, R., \& Sussman, N. (2020). Corona spreads to emerging markets. In S. Djankov \& U. Panizza (Eds.), COVID-19 in developing economies: A CEPR Press VoxEU.org eBook (pp. 362-373). CEPR and the Graduate Institute of International and Development Studies.

EViews, EViews 12 User's Guide. Irvine, CA: IHS Global Inc. http://www.EViews.com/help/helpintro. html\#page/content/Basedata-Frequency_Conversion.html

García-Herrero, A., and Ribakova, E. (2020). COVID-19's reality shock for external-funding dependent emerging economies. Policy contribution 10/2020. Bruegel.

Hair, J. F., Joseph, F., Babin, B. J., Black, W. C., Anderson, R. E., \& Tatham, R. L. (2005). Multivariate data analysis (6th ed.). Macmillan Publishing Company.

Haroon, O., and Rizvi, S. A. R. (2020). Flatten the curve and stock market liquidity: An inquiry into emerging economies. Emerging Markets Finance and Trade 56, p. 10. Taylor \& Francis.

Hasibuan, G. L., Dermawan, D., Ginting, H. S., \& Muda, I. (2020). Allocation of COVID-19 epidemic funding budgets in Indonesia. International Journal of Research and Review, 7(5), 75-80.

Hofmann, B., Shim, I., and Shin, H.S. (2020a). Emerging market economy exchange rates and local currency bond markets amid the COVID-19 pandemic. BIS Bulletin, p. 5. Bank for International Settlements.

Hofmann, B., Shim, I., \& Shin, H. S. (2020). Original sin redux and policy responses in emerging market economies during the COVID-19 pandemic". In S. Djankov \& U. Panizza (Eds.), COVID-19 in developing economies: A CEPR Press VoxEU.org eBook (pp. 353-361). CEPR and the Graduate Institute of International and Development Studies.

Hördahl, P., and Shim, I. (2020). EME bond portfolio flows and long-term interest rates during the COVID-19 pandemic. BIS Bulletin, p. 18. Bank for International Settlements.

International Monetary Fund. (2020a). World economic outlook, April 2020: The great lockdown. International Monetary Fund.

International Monetary Fund. (2020b). World economic outlook, october 2020: A long and difficult ascent. International Monetary Fund.

International Monetary Fund. (2020c). Central bank support to financial markets in the coronavirus pandemic. Special series on COVID-19. International Monetary Fund.

Kohlscheen, E., Mojon, B., and Rees, D. (2020). The macroeconomic spillover effects of the pandemic on the global economy. BIS Bulletin, p. 4. Bank for International Settlements.

Mela, C. F., \& Kopalle, P. K. (2002). The impact of collinearity on regression analysis: The asymmetric effect of negative and positive correlations. Applied Economics, 34, 667-677.

Ozili, P., and Arun, T. (2020). Spillover of COVID-19: Impact on the global economy. https://ssrn.com/ abstract $=3562570$

Patra, M.D., and Ray, P. (2010). Inflation expectations and monetary policy in India: An empirical exploration. IMF Working Paper, Vol. 2010, Issue 084. International Monetary Fund. https://www.elibr ary.imf.org/view/journals/001/2010/084/001.2010.issue-084-en.xml 
Pedroni, P. (1999). Critical values for cointegration tests in heterogeneous panels with multiple regressors. Oxford Bulletin of Economics and Statistics, 61, 653-670. https://doi.org/10.1111/1468-0084. 0610 s 1653

Perkins, D.W., Gnanarajah, R., Labonte, M., and Scott, A. P. (2020). COVID-19 and the banking industry: Risks and policy responses. Congressional research service, p. R46422. US Congress. https:// crsreports.congress.gov/product/pdf/R/R46422

Pesaran, M. H., \& Shin, Y. (1995). An Autoregressive distributed lag modeling approach to co-integration analysis. In S. Strøm (Ed.), Econometrics and economic theory in the 20th century: The ragnar frisch centennial symposium (econometric society monographs) (pp. 371-413). Cambridge University Press. https://doi.org/10.1017/CCOL521633230.011

Pindyck, R.S. (2020). COVID-19 and the welfare effects of reducing contagion. NBER Working Paper Series, p. 27121. National Bureau of Economic Research.

Rismanchi, K. (2020). An aerial view of the bank prudential regulatory response to COVID-19. Institute of International Finance.

Ruiz, À., \& Villafranca, B. (2020). Emerging countries and COVID-19: On the brink of a financial crisis? CaixaBank Research.

Surhayadi, A, Ridho A. I., and Suryadarma, D. (2020). The impact of COVID-19 outbreak on poverty: An estimation for Indonesia. Bulletin of Indonesian economic studies. Taylor \& Francis. https://doi. org/10.1080/00074918.2020.1779390

Susilawati, S., Falevi, R., \& Purwoko, A. (2020). Impact of COVID-19's pandemic on the economy of Indonesia. Budapest International Research and Critics Institute (BIRCI-Journal) Humanities and Social, 3(2), 1147-1156.

Verikios, G., Maura, S., Stojanovski, P., Giesecke, J., and Woo, G. (2011). the global economic effects of pandemic influenza. General Paper G-224. Centre of Policy Studies, Monash University.

Publisher's Note Springer Nature remains neutral with regard to jurisdictional claims in published maps and institutional affiliations. 